\title{
Diatomaceous rocks of the Jawornik deposit (the Polish Outer Carpathians): petrophysical and petrographical evaluation
}

\author{
Beata Figarska-Warchoł, Grażyna Stańczak, Marek Rembiś, Tomasz Toboła \\ AGH University of Science and Technology, Faculty of Geology, Geophysics and Environmental Protection, \\ al. A. Mickiewicza 30, 30-059, Krakow, Poland; \\ e-mail:figarska@agh.edu.pl,stanczak@agh.edu.pl,mrembis@geol.agh.edu.pl,tob@geol.agh.edu.pl \\ (C) 2015 Authors. This is an open access publication, which can be used, distributed and reproduced in any medium according \\ to the Creative Commons CC-BY 4.0 License requiring that the original work has been properly cited.
}

Received: 16 January 2016; accepted: 18 February 2016

\begin{abstract}
Diatomites belonging to a list of raw materials used in the EU criticality assessment are essential to many industrial applications due to a unique combination of their physical properties, i.e. porous and permeable structure, high specific surface area and adsorption capacity, low density and thermal conductivity, and chemical inertness. The present study was undertaken to analyse the relationships between the pore network characteristics, petrophysical parameters, and mineralogical variability of the Lower Miocene diatomites from the Jawornik deposit (Skole Unit, the Polish Outer Carpathians, SE Poland). Five varieties of the diatomites, distinguished on the basis of the macroscopic features, i.e., colour and fracturing effects, have been investigated by SEM, chemical and XRD analysis, mercury intrusion porosimetry, helium pycnometry, and the Vickers hardness tests. Significantly differing are two varieties. The light-coloured, massive and block-forming diatomites (variety BL) consist mainly of poorly cemented siliceous skeletal remains of diatoms, and represent the rocks with high total porosity (38-43\%), low bulk density $\left(1.28-1.38 \mathrm{~g} / \mathrm{cm}^{3}\right)$ and low microhardness $\left(10.7 \mathrm{HV}_{0.3}\right)$. The dark-gray silicified diatomites with a platy or prismatic splitting (variety PD) reveal obscured microfossils of diatoms and are the most compact and hard rocks $\left(80.8 \mathrm{HV}_{0.3}\right)$, with poor total porosity $(17-24 \%)$ and higher bulk density $\left(1.70-1.78 \mathrm{~g} / \mathrm{cm}^{3}\right)$. The spatial distribution of the field identifiable rock varieties allows selective exploitation of the diatomites with the predictable petrophysical characteristics that define their future use.
\end{abstract}

Keywords: critical raw materials, diatomite, silica, scanning electron microscopy (SEM), chemical analysis, porosity, Vickers microindentation hardness

\section{INTRODUCTION}

Diatomites have been included into the group of 41 mineral raw materials identified by the Committee on Critical Mineral Impacts on the US Economy as critical commodities. They have a significant economic importance also for the European Union, revealing their usability in the developments of some innovation technologies (Christmann 2010, Radwanek-Bąk 2011). The deposits of diatomites in Poland occur in the Tertiary strata of the Car- pathians and are located in the Podkarpackie Voivodeship. Initial works on these diatomites were carried out by J. Kotlarczyk in the 1950s and 1960s (Kotlarczyk 1955, 1966). A follow-up in next decades included a petrographic characterization and an evaluation of basic physical properties of these rocks (Russocki 1981, Kotlarczyk et al. 1986, Kotlarczyk 1988b).

Considering their specific physical and chemical properties, such as the low bulk density, high porosity, low thermal conductivity, high content 
of amorphous silica, insolubility in acids and considerable specific surface area, diatomites are used in many technologies, usually associated with the widely understood environmental protection. They are important filtration materials and sorbents in the water and effluent treatment processes, also have other numerous applications, including construction, chemical, foundry and refractive materials industries, various sectors of manufacturing where they are fillers, pesticide carriers, polishing and abrasive materials, they are also used in agriculture (Granops 1989, Smoleńska \& Rembi 2002, Puszkarewicz 2004, Kaleta et al. 2007, Osmanlioglu 2007, Janotka et al. 2014). The sorption properties of diatomites are usually regarded their major property, particularly in adsorption of oil-derived substances and chemical compounds containing heavy metals.

Such a long (and definitely not complete) list of common applications explains why wide research on diatomites focused on improving their many technological properties. For instance the values of mesoporosity of diatomites may be changed to a various degree as a result of calcination (Martinovic et al. 2006, Yılmaz \& Ediz 2008, Ibrahim \& Se$\lim$ 2010, Ediz et al. 2010, van Garderen et al. 2011) or a chemical treatment (Li et al. 2007, Xiong \& Peng 2008, Sungworawongpana \& Pengprecha 2011, Jin et al. 2014). In some other applications, for example in the building industry or the production of abrasives and polishing materials, the mechanical properties of these rocks are an important parameter, and it is not only hardness but also their ability to fracturing and the shape of the grains of aggregates and even of dust particles (van Garderen et al. 2011).

Technological advances in various branches of industry and growing environmental concerns are the reasons of developing new research directions opening wider and wider applicability of diatomites. One of such novel applications is their capability to adsorb from water solutions various salts , mainly chlorides of sodium, magnesium and potassium. Initial results obtained in this range by the authors for various types of diatomites have revealed that these rocks have differing fractal dimensions of their pores, which must result from a variable ordering of the rock pore space and significantly affect the process of salt precipitation and an amount of the salt crystals formed (Stańczak et al. 2015, Toboła et al. 2015).
Many years of research on various diatomite occurrences have shown that even within one deposit these rocks may differ in their mineral compositions, structures and textures (Kotlarczyk 1966, Śliwowa \& Russocki 1980), i.e. some of the features that record diversified conditions of a sediment deposition and diagenesis, sometimes also of rock weathering. The authors have assessed the impact of the lithological variability of the diatomites from Jawornik on their diversification of the chemical composition and physico-mechanical properties. They have also tried to single out the macroscopic features of the rocks with predictably advantageous and inferior technological parameters and determine the reasons controlling such a difference.

\section{MATERIALS AND METHODS}

\section{Materials}

Diatomites occur in the eastern part of the Polish Outer Carpathians in the profile of the youngest, Oligocene-Lower Miocene flysch strata of the Skole Unit. They form three separate horizons that crop out between the Wisłok River on the west and the town of Przemyśl on the east (Fig. 1). The three horizons differ one from another in their lithology, thickness, genesis and assemblage of diatoms (Kotlarczyk 1982).

The first, Early Oligocene horizon is represented by the Diatomite of Futoma Member, occurring in the lower part of the Menilite Formation (formerly the Menilite Beds) below the Kliwa Sandstone Member (Kotlarczyk 1982, Kotlarczyk \& Kaczmarska 1987, Kotlarczyk \& Leśniak 1990, Marcinowski et al. 2011). The second, Upper Oligocene-to-Lower Miocene horizon of the Piątkowa diatomites occurs within the Niebylec Shale Member, whose floor marks the upper border of the Krosno Formation (formerly the Lower Krosno Beds) (Koszarki \& Żytko 1961, Malata 1996). The Niebylec Shale Member itself belongs to the Strzyżów Formation (formerly the Upper Krosno Beds) (Kotlarczyk 1982, Kotlarczyk \& Kaczmarska 1987). The third, Lower Miocenian (Upper Burdigalian) horizon is represented by the Leszczawka Diatomite Member, located in the upper part of the Strzyżów Formation (Koszarski \& Żytko 1961, Kotlarczyk 1966, 1982, Malata 1996). The Menilite, Krosno and Strzyżów formations alongside with the underlaying them 
Globigerina Marl Formation belong to a deposition megasequence that reflects the last stage of a synorogenic closing the sedimentary basins in the Polish part of the Flysch Carpathians, and is accompanied by a volcanic activity (Malata \& Poprawa 2006, Oszczypko 2008, Szydło et al. 2014).

The diatomites belonging to the Leszczawka Diatomite Member form intercalations with the thickness some tens meters, which were identified in axial zones of the Brzuska, Leszczawka and Dydnia synclines. However, the most representative of this horizon are the diatomites of the Leszczawka syncline, where they occur as a complex of around 100-140 m thick, filling the north-eastern limb of this syncline, and extend over $17 \mathrm{~km}$ from Kuźmina on the SE to Huta Poręby on the NW (Kotlarczyk 1982, 1988a, 1988b). In the north-western part of the Leszczawka syncline, in the area of Jawornik Ruski, the member of the Leszczawka diatomites splits into three lithosomes separated by sandstone-shale strata of the Strzyżów Formation. In the middle lithosome, which has the features of the olistostrome structure (Kotlarczyk 1988b), is located the Jawornik deposit of diatomites (Śliwowa \& Russocki 1980), the subject of authors' interest (Fig. 1). The Leszczawka diatomites occurring in Jawornik are brown and beige, massive, generally not laminated rocks, intercalating with brown diatomaceous and siliceous-argillaceous shales, sandstones, cherts, porcelanites and sometimes tuffites. The layers are steeply $\left(75-90^{\circ}\right)$ inclined to SE. Among the diatom assemblage has been found both marine and freshwater varieties, which, alongside sedimentary structures, proves an allochtonous origin of the sediments (redeposition of the detrital material from other parts of the basin by mud flows and submarine slumps olistostromes) (Kotlarczyk 1982, 1988b). Pyroclastics are commonly associated with the siliceous microfossils, because they provide dissolved silica necessary to the development and proliferation of diatoms (Jucha \& Kotlarczyk 1961, Żgiet 1963, Pedersen \& Surlyk 1983, Bromowicz \& Górniak 1988, Owen \& Utha-aroon 1999).

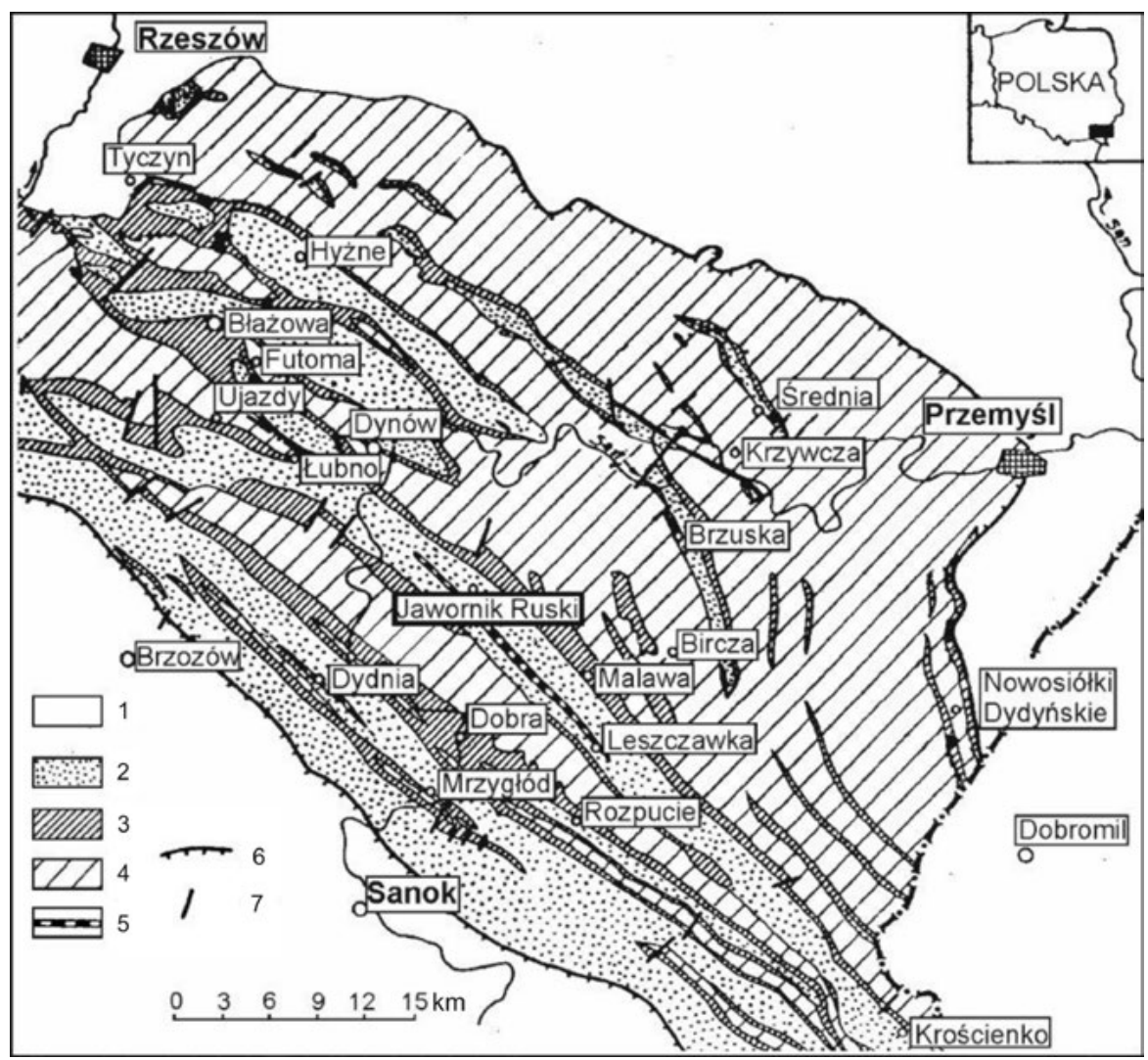

Fig. 1. Geological map of the Skole Unit in the eastern part of the Polish Outer Carpathians (after Kotlarczyk 1982): 1 - Miocen and Quaternary strata of the Carpathian foredeep, 2 - Krosno and Strzyżów Formation (formerly Krosno Beds), 3 - Menilite Formation (formerly Menilite Beds), 4 - strata older than the Menilite Formation, 5 - the Leszczawka Diatomite Member, 6 - major thrust, 7 - faults; the Jawornik deposit - in the centre of map 


\section{Methods}

In the course of fieldwork within the Jawornik deposit, a lithological profile $52.6 \mathrm{~m}$ long exposed in a prospecting trench running NE-SW was described. The profile represents the bottom part of the middle lithosome of the Leszczawka Diatomite Member. Rock samples were collected from 20 layers, of which 14 are diatomites and six shales.

Several samples were taken from each layer and their total of 133 represents different varieties of the diatomites and the shale intercalations. The samples were denoted with the numbers corresponding to successive layers. Thick layers were sampled close to their bottoms, in the middle and in the top parts, and described additionally with the letters A, B and C, respectively. A hand specimen inspection focused on the variability of rock colours, structural and textural features, and also the mode of fragmentation due to weathering.

Preliminary petrographic observations of the diatomaceous rocks were carried out under an optical microscope in the transmitted light on 23 polished thin sections. Ten selected sections were further investigated in a scanning electron microscope (SEM) FEI Quanta 200 FEG (low-vacuum) with a BSE detector coupled to an EDS analyser. Optical microscopy provided data on the major mineral components, and the structure and texture of the diatomaceous rocks. The SEM micrographs were used for quantitative measurements, applying the point method in a square grid, with a distance of $10 \mu \mathrm{m}$ among the measuring points; in each sample a number of the points was between 430 and 677. X-ray diffractometric (XRD) analyses supported the identification of mineral phases and were conducted on 11 samples of diatomites, representing the most variable rock types. An X-ray diffractometer DRON 3.0 was used applying the Debye-Sherrer powder method. The SEM and $\mathrm{XRD}$ analyses were conducted at the Laboratory of Phase, Structural and Textural Investigations, the Faculty of Geology, Geophysics and Environmental Protection of the AGH UST.

The chemical composition of the diatomites was established on 11 samples representing different varieties of these rocks. The powder samples were analysed at the Activation Laboratories Ltd. ACTLABS (Canada) with the ICP-OES method.

The apparent density and water absorption were determined on 133 samples of the diatomites, according to the EN standards (EN-13755:2008, EN-1936:2006), using a saturation and immersion technique (hydrostatic weighing) based on Archimedes' Principle.

Helium pycnometry and mercury intrusion porosimetry were used for pore system characterization of 12 selected samples with diversified physical properties. The analyses were performed at a laboratory of the Faculty of Energy and Fuels of the AGH UST. True density was determined using the gas displacement method based on Boyle's Law, measuring the skeletal (grain) volume under ambient conditions with a helium pycnometer $\mathrm{Mi}$ cromeritics AccuPyc 1330.

The mercury porosimetry tests consist in records of the incremental volumes of mercury intruding into an evacuated pore space of a rock as the external pressure is progressively increased. Assuming that the pore system is composed of bundles of cylindrical tubes (a capillary bundle model), the application of the Washburn equation (Washburn 1921) enables to evaluate the distribution of pore volume accessible by throats of a given effective diameter (Vavra et al. 1992). Bulk density, effective porosity and a volumetric distribution of pore size were measured using a CE Instruments Pascal 140/240/440 high pressure mercury porosimeter. The pressure applied started at $0.114 \mathrm{MPa}$ and ended at $150.21 \mathrm{MPa}$ allows determination of pore-throat diameters between $13.09 \mu \mathrm{m}$ and $0.010 \mu \mathrm{m}$. A value of the surface mercury tension of $0.480 \mathrm{~N} / \mathrm{m}$ and a contact mercury angle on a siliceous rock of $141.3^{\circ}$ were used in the Washburn equation. The total effective porosity was calculated on the basis of the bulk density and true density. The hysteresis occurring between the intrusion and withdrawal curves was calculated for three pressure values: $1 \mathrm{MPa}, 10 \mathrm{MPa}$ and a threshold pressure that differed from 4.114 to $8.005 \mathrm{MPa}$ for each sample.

The dependence between the petrographical characteristics of the diatomites and their resistance to the external stress exerted by a point-acting pressure was tested in seven samples measuring their microhardness. The analyses were carried out applying the Vickers method with a hardness tester Future-Tech FV-700 at a laboratory of the Faculty of Materials Science and Ceramics of the AGH UST. The Vickers hardness HV expresses the resistance of a rock to pressing a pyramidal 
diamond indenter and is calculated using the load exerted by the indenter and the average diagonal of the square-shaped indentation mark (Winkler 1997). With regard to a relatively low hardness of samples, a minimum available load of $2.942 \mathrm{~N}$ $(0.3 \mathrm{kgf})$ of the Vickers indenter was applied. In every sample 20 measurements were made along a line. The results of the microhardness measurements represent a certain approximation to the compression strength. The latter parameter could not be determined due to disintegration of diatomite samples into irregular fragments from which it was not possible to cut samples of the required shape and size. Such an approach is justified by previous such investigations on other materials and carried out by other authors (Glinicki et al. 2003): they showed a strong dependence between these two parameters.

\section{RESULTS AND DISCUSSION}

\section{Hand specimen characteristics of the diatomites}

The Jawornik rocks are light-weight siliceous-clay rocks, usually with a structureless and colours from light creamy and yellowish orange to grey and dark grey. Our description involves mainly their colour and type of disintegration (Tab. 1), as two useful elements making the classification basis proposed earlier by Kotlarczyk (1988a).

Among the rocks of the profile (Fig. 2) predominate massive diatomites with blocky or lumpy disintegration, light creamy (variety BL) (Fig. 3A) or dark creamy, grey and grey-brown (variety BD) (Fig. 3B). The thickness of their layers ranges from $2.1 \mathrm{~m}$ (layer No. 17) to $9.8 \mathrm{~m}$ (layer No. 3). The lighter varieties are compact, but soft or very soft, being easily scratched with a steel implement and sometimes even with a nail (layers Nos. 1, 3 and 17), whereas darker-coloured varieties are harder (layers Nos. 12, 14 and 20). The diatomites of the variety $\mathrm{BL}$ are fine- to medium detrital, usually with the structureless, sometimes diversified by diffusive Liesegang rings developed close to the discontinuity surfaces covered by rusty-orange coatings of iron oxides/hydroxides. Lamination was observed in one layer only (No. 17), whose another rare feature is unusually light, almost white colour of the diatomites. The white laminae intercalate with the creamy ones, probably with higher silica content. A network of fractures that randomly intersect both laminae types are filled with a darker substance of a siliceous character. The massive diatomites usually grade upward into more clayey rocks, which is marked by the darker tint of their basic colour.

Thick layers of the blocky diatomites are intercalated with the diatomite layers with platy or prismatic disintegration: they split into the plates around $5 \mathrm{~cm}$ thick or irregular, less or more sharp-edged fragments. As in the former group of diatomites, also these rocks are composed of two colour varieties, the light creamy, light brown and light grey one (PL) (Fig. 3C) and the dark grey one (PD) (Fig. 3D), both with yellow to rusty coatings on the fracture surfaces.

Table 1

Thickness contributions of the lithological varieties to the profile of the Jawornik deposit

\begin{tabular}{|c|c|c|c|}
\hline & \multicolumn{2}{|c|}{$\begin{array}{c}\text { Contribution to the } \\
\text { profile [\%] }\end{array}$} \\
\hline \multirow{2}{*}{$\begin{array}{l}\text { Diatomites with blocky or lumpy } \\
\text { disintegration }\end{array}$} & $\begin{array}{l}\text { light creamy }(\mathbf{B L}) \\
\text { layers Nos. } 1,3,17\end{array}$ & 40.3 & \multirow{2}{*}{71.5} \\
\hline & $\begin{array}{l}\text { dark creamy, grey, grey-brown (BD) } \\
\text { layers Nos. 12, 14, } 20\end{array}$ & 31.2 & \\
\hline \multirow{2}{*}{$\begin{array}{l}\text { Diatomites with platy or prismatic } \\
\text { disintegration }\end{array}$} & $\begin{array}{l}\text { light creamy, light brown, light grey (PL) } \\
\text { layers Nos. } 4,6,10\end{array}$ & 8.0 & \multirow{2}{*}{11.0} \\
\hline & $\begin{array}{l}\text { dark grey }(\mathbf{P D}) \\
\text { layers Nos. 8, 11, 13, } 15\end{array}$ & 3.0 & \\
\hline $\begin{array}{l}\text { Diatomites with nodular } \\
\text { disintegration }\end{array}$ & $\begin{array}{l}\text { yellowish orange }(\mathrm{N}) \\
\text { layer No. } 2\end{array}$ & \multicolumn{2}{|c|}{0.4} \\
\hline \multicolumn{2}{|c|}{$\begin{array}{l}\text { Shales (grey, dark grey, yellowish grey, rusty) (Sh) } \\
\text { layers Nos. } 5,7,9,16,18,19\end{array}$} & \multicolumn{2}{|c|}{17.1} \\
\hline
\end{tabular}




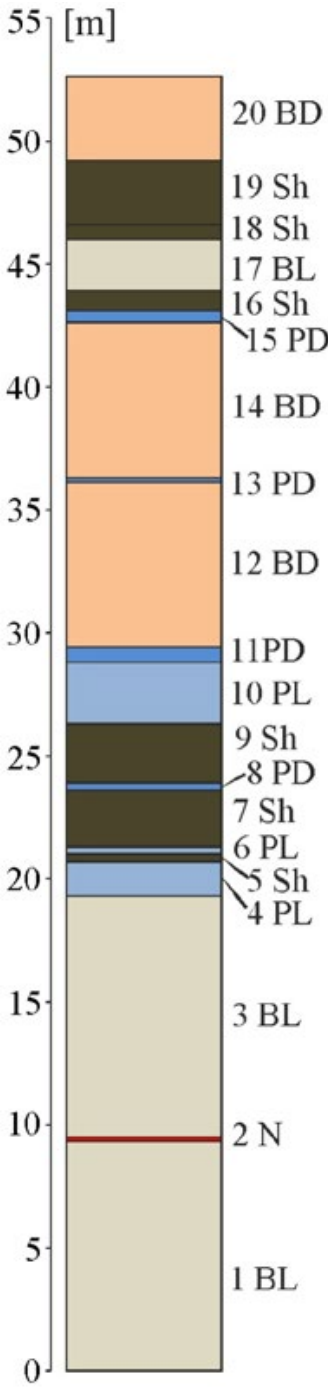

Fig. 2. Lithological profile of the Leszczawka Diatomite Member cropping out in a prospecting trench in the Jawornik deposit (numbers of layers and abbreviations of varieties see the Table 1)

The variety PL (layers Nos. 4, 6 and 10) sometimes contains more clayey or sandy components and forms three layers with a considerably lower thicknesses $(0.3-2.5 \mathrm{~m})$ than the diatomites of the varieties $\mathrm{BL}$ and $\mathrm{BD}$. The variety $\mathrm{PD}$ is developed as four thin layers $(0.2-0.6 \mathrm{~m})$ of dark grey and hard, silicified diatomites, disintegrating into sharp-edged, irregular fragments (layers Nos. 8, 11,13 and 15). They accompany in the profile the darker varieties of the blocky diatomites (BD) and shales. From the degree of the profile exposition it is not possible to unambiguously determine the position of the PD diatomites to the adjacent rocks, but their lensoidal forms sometimes revealed allow suggesting that they do not occur as continuous horizons but rather as thin lenses among other diatomite varieties. The total contribution of the diatomites with the platy or prismatic splitting equals $11 \%$ of the whole profile (Tab. 1).

In the lower part of the profile, among thick layers of the massive diatomites occurs a thin layer (about $0.2 \mathrm{~m}$ ) of diatomite with a medium hardness, disintegrating into irregular nodules (variety N) (Fig. 3E). The rock (layer No. 2) contains an elevated iron content, which is proved by its yellowish orange colour. The fracture surfaces are covered by black coatings, most probably of manganese oxides/hydroxides.

Shales (Sh) were observed in two zones. The first of them is located above the lower, $21 \mathrm{~m}$ thick, set of diatomites (Fig. 2). The zone is composed of three shale layers, grey and rusty, with the thickness $0.3 \mathrm{~m}, 2.3 \mathrm{~m}$ and $2.4 \mathrm{~m}$ (layers Nos. 5, 7 and 9). Above the next set of diatomites with the thickness about $19 \mathrm{~m}$ is located the other zone of dark grey and yellowish grey shales, developed as three layers $0.8 \mathrm{~m}, 0.6 \mathrm{~m}$ and $2.6 \mathrm{~m}$ thick (layers Nos. 16, 18 and 19) (Fig. 3F). The shales of both zones do not show any gradual facies transition in respect to the sets of the massive diatomites. Such a development of the profile may be a result of a sudden change of sedimentary conditions in the basin or of the submarine slumping. The shales usually split into small fragments, and after soaking easily disintegrate in water. Only occasionally few their fragments preserve their forms in contact with water, which suggests a local silicification. In one of the layers they show an admixture of a sandy material. The total thickness of the shales makes up about $17 \%$ of the profile exposed in the trench (Tab. 1).

\section{Petrographical characteristics of diatomites}

SEM observations indicate that the diatom debris prevail over the whole specimens in the diatomites, and the grain material is enclosed in a siliceous-clay groundmass of the matrix type. The amount of diatoms ranges from $36 \%$ to $61 \%$, and is higher in the light- and dark-coloured diatomites with the blocky disintegration (BL and BD), which contain 41.2-61.0\% diatoms (Tab. 2). In the PL and PD rock types with the platy or prismatic disintegration this amount is around $45 \%$, and in the nodular diatomites $(\mathrm{N})$ only $36 \%$. 
It should be emphasised, however, that the minimum size of the diatom fragments identifiable in the SEM images is around $2.5-3 \mu \mathrm{m}$. Therefore, all the siliceous particles smaller than $2.5-3 \mu \mathrm{m}$ were considered as the groundmass and real diatom contents may be higher even by several percents. The content of diatoms varies even within the same layer (see samples $1 \mathrm{~A}$ and $1 \mathrm{C}$ ). In two other thin sections of the dark grey prismatic diatomites (PD), observations under the polarizing microscope have revealed about $20-30$ vol.\% of diatoms. The fossils are present even in a thin section representing shales (Sh) but in a significantly lesser amount of several percents.

The biggest diatom specimens reach a size 50-100 $\mu \mathrm{m}$. Their shapes are elongated (eliptic, rhomboidal, crescent-like) and circular, typical of the species identified, among others, by Kotlarczyk (1982). The diatom frustules are composed of loosely bound parts: the upper (epitheca) and lower (hypotheca) covers; the frustules have a sophisticated ornamentation, full of hollows, holes and small ribs that strengthen their structure (Fig. 4A).
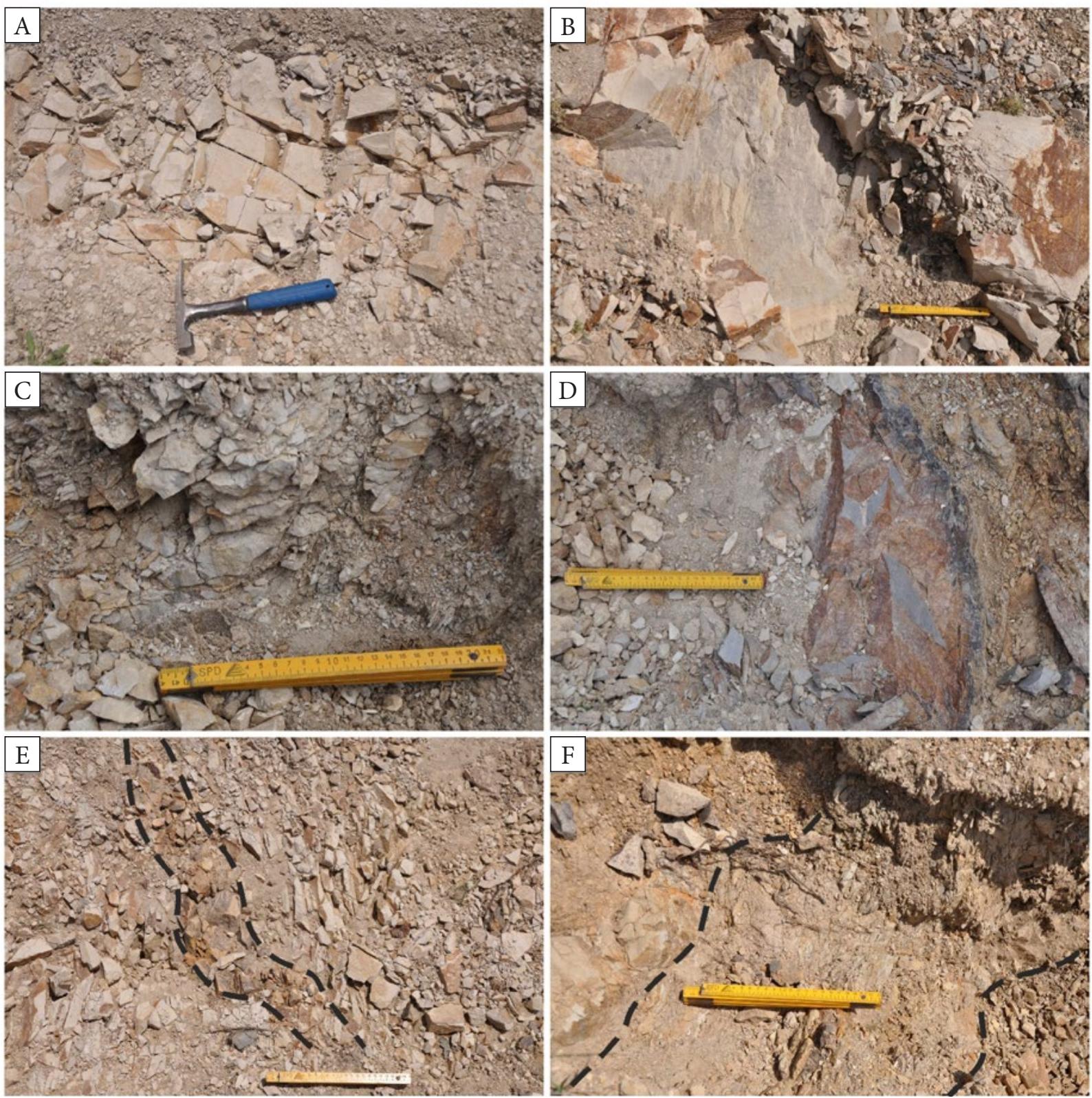

Fig. 3. Lithological varieties of diatomaceous rocks of the Leszczawka Diatomite Member distinguished in the Jawornik deposit: blocky diatomites: A) light creamy - BL; B) dark creamy - BD; prismatic and platy diatomites: C) light creamy - PL; D) dark creamy - PD; E) diatomite disintegrating into irregular nodules - N; F) shales - Sh 
Table 2

Mineral composition (vol.\%) of the Jawornik diatomites based on the SEM micrographs

\begin{tabular}{|c|c|c|c|c|c|c|c|c|c|}
\hline $\begin{array}{c}\text { Diatomite } \\
\text { variety }\end{array}$ & $\begin{array}{c}\text { Sample } \\
\text { No. }\end{array}$ & Diatoms & Quartz & Micas & Feldspars & Glauconite & $\begin{array}{c}\text { Sponge } \\
\text { spicules }\end{array}$ & $\begin{array}{c}\text { Ground- } \\
\text { mass }\end{array}$ & $\begin{array}{c}\text { Percentage of full diatoms } \\
\text { in the sum of full diatoms } \\
\text { and their fragments [\%] }\end{array}$ \\
\hline BL & 17 & 59.3 & 1.4 & 2.8 & 1.6 & 0.8 & 0.4 & 33.8 & 17.3 \\
BL & $1 \mathrm{C}$ & 48.2 & 5.2 & 2.8 & 0.7 & 1.1 & 0.0 & 42.1 & 36.6 \\
BL & $1 \mathrm{~A}$ & 43.4 & 6.6 & 2.2 & 2.2 & 1.7 & 0.7 & 43.3 & 44.2 \\
\hline $\mathrm{BD}$ & 20 & 55.2 & 8.6 & 2.5 & 1.0 & 3.2 & 0.0 & 29.6 & 45.7 \\
$\mathrm{BD}$ & $14 \mathrm{~A}$ & 61.0 & 5.4 & 1.5 & 0.5 & 0.3 & 0.3 & 31.0 & 35.6 \\
$\mathrm{BD}$ & $12 \mathrm{~A}$ & 41.2 & 6.8 & 2.6 & 1.6 & 0.8 & 0.0 & 47.1 & 37.5 \\
\hline $\mathrm{PL}$ & 10 & 44.8 & 8.0 & 2.6 & 1.9 & 0.3 & 0.2 & 42.2 & 27.3 \\
\hline $\mathrm{PD}$ & 8 & 44.7 & 3.4 & 1.0 & 0.6 & 0.3 & 0.0 & 50.0 & 17.9 \\
\hline $\mathrm{N}$ & 2 & 36.0 & 6.7 & 3.4 & 3.9 & 1.3 & 0.0 & 48.7 & \\
\hline
\end{tabular}

The elongated fragments of diatoms show in some thin sections a linear arrangement, alternating with micas, the siliceous-clay substance of the groundmass and iron-rich substance, imposing an effect of lamination. Such a structure is weakly expressed in the $\mathrm{BL}$ and $\mathrm{BD}$ varieties and sometimes disappears within a single layer or even in a single thin section. In some thin sections of the PL diatomite variety with platy disintegration, the lamination is slightly better developed, being stronger in the PD variety and, obviously, very distinct in the shales (Sh).

Detrital grains, which make a significantly minor fraction of the diatomite components are randomly distributed. Quartz is the most common of them and occurs in the range $1.4-8.6$ vol.\% (Tab. 2). Its grains are usually some tens of micrometers large and reach the size $120 \mu \mathrm{m}$. They are angular and usually have signs of dissolving of their surfaces; few of them are fractured (Fig. 4B). The next of the granular components are light-coloured micas that make up usually around 2 vol.\%. Feldspars occur occasionally, their surfaces are commonly altered by partial weathering. In X-ray investigations the reflections of albite have been identified (Fig. 5). Fragmented spiculae of siliceous sponges and glauconite occur in traces, the latter occurs as aggregates of considerable sizes that reach $110 \mu \mathrm{m}$. The total of granular components is in the range 5.3-15.3 vol.\%. Their lowest contents have been found in the silicified variety of dark-coloured, prismatically disintegrating diatomite (PD) No. 8 and the light-coloured, laminated diatomite (BL) No. 17. Both samples have a similar, high ratio of the number of diatom debris to the total of these debris and well preserved, whole specimens of diatoms (Tab. 2).

Groundmass is a significant component of the diatomites; its content ranges between 30 and 50 vol.\%. Adapting the nomenclature of detrital rocks, it can be described as of a porous and in places even a basal type. The major components of the groundmass are silica and clay minerals. The XRD analyses indicated that it is silica of a various degree of ordering (Fig. 5). The lowest ordering is represented by opal-A occurring in all the samples and identified based on a diffused reflection with a $d_{\mathrm{hkl}}$ value around $4 \AA$. In diatomites, which are multicomponental rocks, the presence of this reflection points to a significant amount of this mineral phase (Pawloski 1985). Opal-A precipitates from solutions highly saturated with silica (Williams \& Crerar 1985). According to Avramenko (2015), it is a common component of diatom frustules. In the Jawornik diatomites opal-A forms irregular, almost isotropic accumulations, randomly distributed within the groundmass. Higher-ordered variety of silica (opal-CT) occurs in some samples only, the most distinctly in sample 8 (PD), which represents the diatomite subjected to advanced silicification. Opal-CT, a phase of weak solubility, originates due to recrystallization of amorphous silica (Jones \& Segnit 1971, 1972, Flörke et al. 1991, Elzea et al. 1994, Graetsch 1994). 


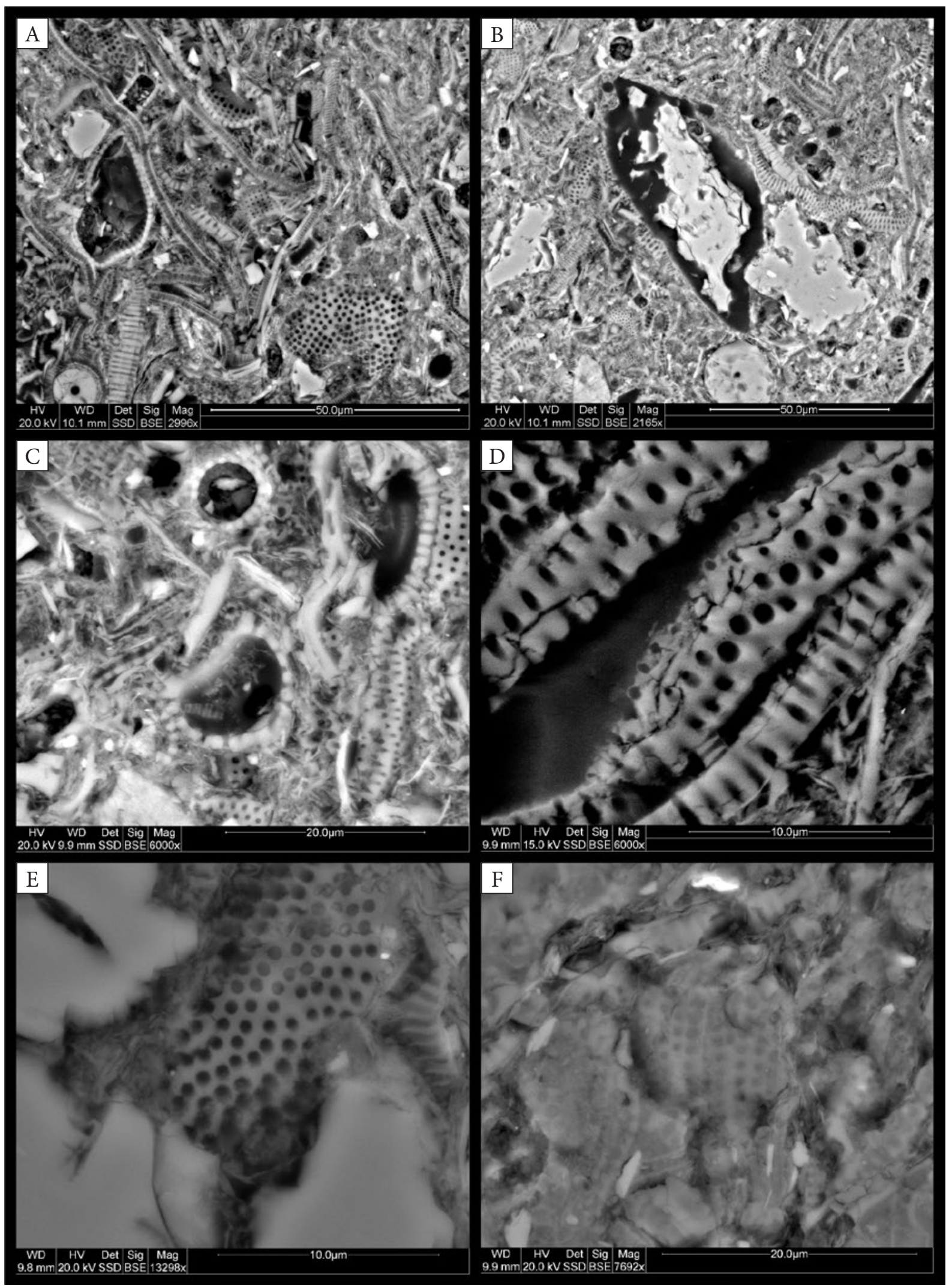

Fig. 4. Backscatter scanning electron microscope micrographs of diatomaceous rocks showing: A) variations of diatom frustules and their debris (sample 12, variety BD); B) partially dissolved detrital quartz grain with fractures (sample 12, variety BD); C) habit of pore-filling clay minerals (sample 14, variety BD); D) porous nanostructure of diatoms (sample 12, variety BD); E) amorphous silica fills some pores of a diatom frustule, but other are partially dissolved (sample 1, variety BL); F) closing of fine pores within a diatom frustule by amorphous silica (sample 8, variety PD) 


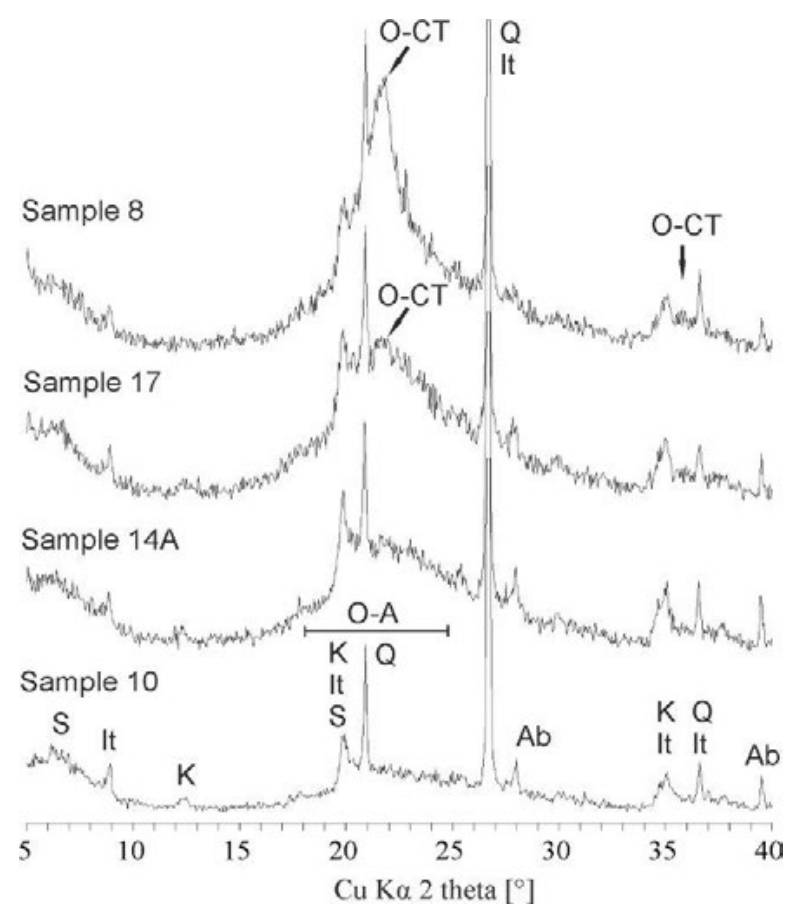

Fig. 5. X-ray diffraction patterns of diatomaceous rocks illustrating detection of quartz (Q), opal-A (O-A), opal-CT $(\mathrm{O}-\mathrm{CT})$, illite (It), smectite or mixed-layered illite-smectite $(\mathrm{S})$, kaolinite $(K)$, and albite $(A b)$

In X-ray patterns weak diagnostic reflections correspond to illite, kaolinite and the minerals of the smectite group, the minerals which were also mentioned by Kotlarczyk (1988b). Of the clay minerals mentioned, forms with morphologies typical of illite and smectites were observed only in the SEM images (Fig. 4C). Investigations of similar sediments (Wey \& Siffert 1961, Siever \& Woodford 1973, Maynard 1975, Sigg \& Stumm 1981, Williams \& Crerar 1985) indicate that clay minerals present within a diatomitic mud can adsorb silica up to the amounts corresponding to their adsorption capacity. Smectites, and also part of the opaline silica, called by Sohling et al. (2009) and Emmerich et al. (2010) the amorphous silica or the silica gel, may be products of hydrolytic processes developing within pyroclastic deposits associated with the volcanic activity during closing stages of sedimentary basins (Malata \& Poprawa 2006, Oszczypko 2008, Szydło et al. 2014). The same origin of these mineral components was postulated by Wieser (1969) in his paper on clinoptilolite from the Eocenian shales of the Futoma area.

Besides silica and clay minerals, the common minor components of the groundmass are the organic substance and iron oxides/hydroxides. The lack of X-ray reflections that could be ascribed to the iron-bearing phases must result from their contents below the detection limit of the method and/or their being amorphous compounds.

The diatomites contain many pores with various sizes and shapes. Their presence indicates that the diagenetic processes within the siliceous-clay mud were of minor intensity. Intergranular pores have irregular shapes as their walls are formed by randomly spaced diatom frustules, flakes of clay minerals and micas, corroded quartz and feldspar grains, and irregular accumulations of other mineral components (Fig. 4A, B, C). The pores are mostly interconnected and form a system of openings accessible to a transport of solutions and gases.

In the SEM images, vast voids are observed inside the diatom frustules (Fig. 4A, C) and the total of such pores is between 5.6 and $10.9 \%$. Besides, there are also fine voids that represent an element of the pore biosystem of diatoms themselves (Fig. 4D). The smallest, still observable pores of the frustules have the sizes around $0.1 \mu \mathrm{m}$, which is greater than the size of the smallest pores occurring within the biostructure of the diatoms (Losic et al. 2007). The presence of such a well developed system of the fine, biostructural pores whose volume is difficult to measure in microscopic investigations is a reason that the content of the pores calculated from these observations does not correspond to a real porosity of diatomites. In some diatoms the pores are partly filled with amorphous silica. The shapes of such pores are not so spherical as those of the hollow pores, moreover their diversified sizes within a single shell indicate that prior to cementation the diatoms were subject to dissolution (Fig. 4E). Dissolving microfossils with a distinct ornamentation, composed of amorphous silica (opal-A), was described by Hurd (1973), Kastner et al. (1977) and Iler (1979). The phenomenon is usually followed by local reprecipitation of relatively weaker soluble silica variety denoted as opal-A' (Hein \& Scholl 1978). The process can be almost instantaneous which is proved by the precipitation of opal-A' in siliceous muds already in the early postdepositional stage of diagenesis (Williams et al. 1985).

\section{Chemical analysis}

Eleven selected samples subject to chemical analyses represent all the distinguished diatomite varieties. 
Table 3

Chemical composition (wt.\%) of selected samples of diatomaceous rocks from the Jawornik deposit

\begin{tabular}{|c|c|c|c|c|c|c|c|c|c|c|c|c|}
\hline $\begin{array}{c}\text { Diatomite } \\
\text { variety }\end{array}$ & $\begin{array}{c}\text { Sample } \\
\text { No. }\end{array}$ & $\mathrm{SiO}_{2}$ & $\mathrm{Al}_{2} \mathbf{O}_{3}$ & $\mathrm{Fe}_{2} \mathbf{O}_{3}(\mathbf{T})$ & $\mathbf{M n O}$ & $\mathbf{M g O}$ & $\mathbf{C a O}$ & $\mathbf{N a}_{2} \mathbf{O}$ & $\mathbf{K}_{2} \mathbf{O}$ & $\mathbf{T i O}_{2}$ & $\mathbf{P}_{2} \mathbf{O}_{5}$ & $\mathbf{L O I}$ \\
\hline $\mathrm{BL}$ & 17 & 83.86 & 6.45 & 1.43 & 0.006 & 0.55 & 0.26 & 0.20 & 1.05 & 0.284 & 0.02 & 6.82 \\
$\mathrm{BL}$ & $1 \mathrm{C}$ & 76.46 & 9.28 & 2.69 & 0.011 & 0.70 & 0.27 & 0.32 & 1.39 & 0.393 & 0.03 & 7.09 \\
$\mathrm{BL}$ & $1 \mathrm{~B}$ & 79.15 & 8.90 & 2.34 & 0.007 & 0.66 & 0.26 & 0.28 & 1.35 & 0.375 & 0.03 & 7.17 \\
$\mathrm{BL}$ & $1 \mathrm{~A}$ & 77.17 & 8.73 & 2.21 & 0.009 & 0.64 & 0.2 & 0.3 & 1.31 & 0.369 & 0.02 & 6.98 \\
\hline $\mathrm{BD}$ & 20 & 72.88 & 11.29 & 2.31 & 0.008 & 0.69 & 0.31 & 0.47 & 1.74 & 0.503 & 0.04 & 8.20 \\
$\mathrm{BD}$ & $14 \mathrm{C}$ & 75.18 & 7.82 & 5.00 & 0.011 & 0.59 & 0.28 & 0.26 & 1.20 & 0.318 & 0.05 & 9.58 \\
$\mathrm{BD}$ & $14 \mathrm{~A}$ & 77.00 & 8.04 & 1.84 & 0.010 & 0.56 & 0.23 & 0.29 & 1.25 & 0.337 & 0.02 & 10.26 \\
$\mathrm{BD}$ & $12 \mathrm{~B}$ & 78.74 & 8.48 & 2.96 & 0.007 & 0.62 & 0.32 & 0.28 & 1.28 & 0.347 & 0.02 & 7.66 \\
\hline $\mathrm{PL}$ & 10 & 74.47 & 11.51 & 3.04 & 0.013 & 0.84 & 0.37 & 0.44 & 1.79 & 0.499 & 0.04 & 7.76 \\
\hline $\mathrm{PD}$ & 8 & 84.79 & 5.13 & 1.18 & 0.008 & 0.45 & 0.27 & 0.18 & 0.89 & 0.223 & 0.04 & 7.81 \\
\hline $\mathrm{N}$ & 2 & 61.23 & 8.14 & 17.24 & 1.183 & 0.61 & 0.20 & 0.29 & 1.17 & 0.334 & 0.23 & 9.74 \\
\hline
\end{tabular}

Notes: LOI - loss on ignition.

They contain $72.88-84.79$ wt.\% $\mathrm{SiO}_{2}$ except for the diatomite with nodular disintegration (sample 2) that contains only $61.23 \mathrm{wt} . \% \mathrm{SiO}_{2}$ (Tab. 3).

The content of $\mathrm{Al}_{2} \mathrm{O}_{3}$ changes in the range $6.45-11.51 \%$ and, generally, does not depend on the diatomite variety as it is with the $\mathrm{SiO}_{2}$ content. The elevated contents of alumina in samples No. 10 (variety PL) and No. 20 (variety BD) can be explained by higher amounts of clay minerals, which have been identified using the XRD method as kaolinite, illite and smectites. Aluminium is also an element contained in feldspars, muscovite and glauconite, the minerals present in minor amounts and in all the samples.

Elevated losses on ignition (LOI) are in samples numbered $14 \mathrm{~A}, 14 \mathrm{C}$ and 2 . The first two represent the rock varieties with darker, colour and both their features (LOI and colour) depend probably upon the presence of a higher amount of the organic substance. In turn, sample 2 is yellowish orange and duly contains significantly higher iron content, equal to $17.24 \% \mathrm{Fe}_{2} \mathrm{O}_{3}$. Despite such a high content of this component, no iron-bearing phases have been detected with XRD, which indicates their amorphous nature (Derkowski et al. 2015).

\section{Chemical composition of the groundmass}

Using the results of the rock chemical analyses and the microscopic quantification of the detrital rock components, an attempt was made to estimate quantitatively also the distinguishable components of the groundmass. They could be only generally identified both under an optical and in scanning microscope, whereas the XRD analyses provide a combined qualitative result on all crystalline rock components but their contents can be only assessed in a relative manner. The results of authors' calculations are tentative (Tab. 4), because a number of preliminary assumptions had to be made. According to the results of microscopic observations and the XRD analyses, it was assumed that the groundmass is composed of amorphous silica (containing 10\% micellar water in case of the samples with opal-A and 5\% for the samples with opal-CT), clay minerals (illite, kaolinite and smectites in variable ratios) and iron oxides/hydroxides (recalculated into hematite) and organic substance (calculated as the difference between LOI and the amount of micellar water in amorphous silica). It was also assumed that light-coloured micas have a chemical composition of muscovite, the feldspars are represented by albite, and the frustules of diatoms and the spiculae of sponges are composed of amorphous silica. The averaged chemical compositions of glauconite and clay minerals were accepted following the data of Borkowska \& Smulikowski (1973) and Bolewski \& Manecki (1993). 


\section{Table 4}

Calculated composition of the diatomite groundmass (estimations made on the basis of chemical and microscopic rock analyses and the assumptions described in the text above)

\begin{tabular}{|c|c|c|c|c|c|c|}
\hline \multirow{2}{*}{$\begin{array}{l}\text { Diatomite } \\
\text { variety }\end{array}$} & \multirow{2}{*}{$\begin{array}{l}\text { Sample } \\
\text { No. }\end{array}$} & \multicolumn{4}{|c|}{$\begin{array}{l}\text { Calculated content of groundmass components } \\
{[\%]}\end{array}$} & \multirow{2}{*}{$\begin{array}{c}\text { Total of } \\
\text { calculated } \\
\text { groundmass } \\
\text { components } \\
{[\%]}\end{array}$} \\
\hline & & opal-A/opal-CT & $\begin{array}{c}\text { clay } \\
\text { minerals }\end{array}$ & $\begin{array}{l}\text { iron oxides/ } \\
\text { hydroxides }\end{array}$ & $\begin{array}{l}\text { organic } \\
\text { substance }\end{array}$ & \\
\hline $\mathrm{BL}$ & 17 & $19-21$ & $15-20$ & $\sim 1$ & traces & $37-40$ \\
\hline $\mathrm{BL}$ & $1 \mathrm{C}$ & $12-17$ & $23-32$ & $\sim 2$ & $\sim 1$ & $43-48$ \\
\hline $\mathrm{BL}$ & $1 \mathrm{~A}$ & $18-22$ & $21-29$ & $\sim 1$ & $\sim 1$ & $45-50$ \\
\hline $\mathrm{BD}$ & 20 & $0-4$ & $28-39$ & $\sim 1$ & $3-4$ & $36-41$ \\
\hline $\mathrm{BD}$ & $14 \mathrm{~A}$ & $2-7$ & $22-30$ & $\sim 1$ & $\sim 4$ & $33-37$ \\
\hline $\mathrm{BD}$ & $12 \mathrm{~B}$ & $22-27$ & $21-29$ & $\sim 2$ & $\sim 5$ & 55-59 \\
\hline PL & 10 & $5-11$ & $30-41$ & $\sim 2$ & $2-3$ & $45-51$ \\
\hline $\mathrm{PD}$ & 8 & $33-35$ & $14-19$ & $\sim 1$ & $\sim 1.5$ & $51-54$ \\
\hline $\mathrm{N}$ & 2 & $8-11$ & $17-24$ & $16-17$ & $5-6$ & $50-54$ \\
\hline
\end{tabular}

The results (Tab. 4) indicate that in the diatomites of the variety BL the siliceous and clay components of the groundmass occur in comparable amounts from a dozen or so to about thirty percent. In samples $14 \mathrm{~A}$ and 20 of the variety $\mathrm{BD}$, the contents of the opal groundmass are minor, around several percents. As the microscopic quantification gives a significantly higher content of diatoms in these two rocks, it can be accepted that the dissolution of their diatoms was not so intensive than that in the layer represented by sample $12 \mathrm{~B}$, where the dissolution followed by silica reprecipitation have resulted in the opal content of the groundmass in the range $22-27 \%$. The opal content of the groundmass of the variety PL is low but a content of clay minerals is high, whereas the variety $\mathrm{N}$ at comparably low opal content has an unusually high amount of iron oxides/hydroxides equal to $16-17 \%$. As in the remaining samples this amount does not exceed $2 \%$, the role of the iron oxides/hydroxides compounds in imposing the colour on the diatomites is close to nil. Thus, a more important role may be ascribed to the organic substance, whose amounts from a fraction of a percent to about $5 \%$ distinctly correlate with the colour of diatomites. For instance, the light-coloured blocky diatomites BL contain from traces to around $1 \%$ of organic substance, while the darker-coloured diatomites $\mathrm{BD}$ with the same blocky disintegration about $3-5 \%$ of organic substance. An exception makes sample 8 , which at a low content of the organic substance is dark-coloured. In contrast, despite its highly similar chemical composition, sample 17 (BL) is strongly light-coloured. Both these varieties are characterized by the highest contents of $\mathrm{SiO}_{2}$, around $84 \%$, the lowest, $5-6 \%$ contents of $\mathrm{Al}_{2} \mathrm{O}_{3}$ and the lowest contents of the remaining oxides, also the lowest value of LOI. The estimated compositions of their groundmass are also similar considering clay minerals, iron oxides/hydroxides and the organic substance. The two samples differ in their contents of diatoms (Tab. 2) and the calculated content of opal in their groundmass: the latter reaches $35 \%$ in sample 8 , while in sample 17 is around $20 \%$. These features correspond with the lowest content of the detrital quartz and the highest, X-ray estimated content of amorphous silica. This silica occurs as a component of both the numerous, strongly fragmented diatoms and cement. There are two possible reasons differencing the colours as well as the disintegration forms of these two rock varieties: (1) the type, amount and distribution of the components built of silica (diatom frustules, groundmass, detrital quartz, sponge spiculae), and (2) the pore structure development. The light-coloured diatomites of the layer 17 are composed first of all of finely fragmented diatoms loosely dispersed in the siliceous-clay 
groundmass; it is thus this groundmass that dissipates the stress that leads to rock disintegration. In the diatomite variety represented by sample 8 , its fragmented diatoms were strongly joined with silica cement; additionally, rock silicification formed rigid, silica-rich zones separated by parallel zones of clay-rich accumulations, whose presence results in the disintegration of the rock into elongated, sharp-edged fragments.

\section{Apparent density and water absorption}

The values of the bulk density range between $1.20 \mathrm{~g} / \mathrm{cm}^{3}$ and $1.66 \mathrm{~g} / \mathrm{cm}^{3}$, and the water absorption between $13.22 \%$ and $35.34 \%$ (Tab. 5). The two parameters show the obvious and commonly described in the literature mutual, strong and reversely proportional dependence. The extreme values correspond to the diatomite varieties $\mathrm{PD}$ and $\mathrm{BL}$ (samples 8 and 17, respectively). Low water absorption of sample 8 results, without any doubts as the process is visible in scanning microscopy, from the rock silicification that closed the intergranular pore space and fine pores within the diatoms (Fig. 4F).

The diatomites of the variety BL have the highest average water absorption $30.85-35.34 \%$ and the lowest apparent density $1.20-1.26 \mathrm{~g} / \mathrm{cm}^{3}$. These values and the rock features described earlier are characteristic of the diatomites sensu stricto, distinguished by Kotlarczyk (1966). Darker-coloured diatomites of the variety $\mathrm{BD}$ have lower water absorption $21.74-26.45 \%$ and higher apparent density $1.31-1.49 \mathrm{~g} / \mathrm{cm}^{3}$. Similar values of both rock parameters have the light-coloured diatomites PL with platy or prismatic disintegration and the nodular diatomites $\mathrm{N}$. The dark-coloured diatomites PD have the lowest average water absorption, between $13.22 \%$ and $19.09 \%$, at the average apparent densities between $1.53 \mathrm{~g} / \mathrm{cm}^{3}$ and $1.66 \mathrm{~g} / \mathrm{cm}^{3}$.

Table 5

Extreme and average values of the water absorption and apparent density

\begin{tabular}{|c|c|c|c|c|c|c|c|}
\hline \multirow{2}{*}{$\begin{array}{c}\text { Diatomite } \\
\text { variety }\end{array}$} & \multirow{2}{*}{$\begin{array}{c}\text { Sample } \\
\text { No. }\end{array}$} & \multicolumn{3}{|c|}{ Water absorption [\%] } & \multicolumn{3}{c|}{ Apparent density [g/cm $\left.{ }^{3}\right]$} \\
\cline { 3 - 8 } & minimum & maximum & average & minimum & maximum & average \\
\hline BL & 17 & 33.54 & 36.16 & $\mathbf{3 5 . 3 4}$ & 1.18 & 1.22 & $\mathbf{1 . 2 0}$ \\
BL & 3 & 31.34 & 32.71 & $\mathbf{3 2 . 1 7}$ & 1.23 & 1.25 & $\mathbf{1 . 2 4}$ \\
BL & $1 \mathrm{C}$ & 29.94 & 32.21 & $\mathbf{3 1 . 3 3}$ & 1.25 & 1.27 & $\mathbf{1 . 2 6}$ \\
BL & $1 \mathrm{~B}$ & 28.92 & 33.30 & $\mathbf{3 0 . 8 5}$ & 1.22 & 1.30 & $\mathbf{1 . 2 6}$ \\
BL & $1 \mathrm{~A}$ & 30.11 & 32.84 & $\mathbf{3 1 . 0 6}$ & 1.23 & 1.28 & $\mathbf{1 . 2 6}$ \\
\hline BD & 20 & 20.61 & 22.66 & $\mathbf{2 1 . 7 4}$ & 1.45 & 1.52 & $\mathbf{1 . 4 9}$ \\
BD & $14 \mathrm{C}$ & 22.71 & 23.81 & $\mathbf{2 3 . 3 0}$ & 1.35 & 1.38 & $\mathbf{1 . 3 6}$ \\
BD & $14 \mathrm{~B}$ & 25.80 & 26.93 & $\mathbf{2 6 . 4 4}$ & 1.30 & 1.32 & $\mathbf{1 . 3 1}$ \\
BD & $14 \mathrm{~A}$ & 18.42 & 24.90 & $\mathbf{2 2 . 7 4}$ & 1.34 & 1.52 & $\mathbf{1 . 4 0}$ \\
BD & $12 \mathrm{C}$ & 23.26 & 26.20 & $\mathbf{2 4 . 6 4}$ & 1.34 & 1.37 & $\mathbf{1 . 3 5}$ \\
BD & $12 \mathrm{~B}$ & 24.01 & 28.52 & $\mathbf{2 6 . 4 5}$ & 1.29 & 1.35 & $\mathbf{1 . 3 1}$ \\
BD & $12 \mathrm{~A}$ & 24.84 & 27.94 & $\mathbf{2 5 . 9 3}$ & 1.31 & 1.35 & $\mathbf{1 . 3 3}$ \\
\hline PL & 10 & 17.10 & 24.72 & $\mathbf{2 1 . 2 9}$ & 1.43 & 1.72 & $\mathbf{1 . 5 5}$ \\
PL & 6 & 26.39 & 30.83 & $\mathbf{2 9 . 4 0}$ & 1.27 & 1.34 & $\mathbf{1 . 2 9}$ \\
PL & 4 & 27.62 & 29.45 & $\mathbf{2 8 . 6 4}$ & 1.25 & 1.42 & $\mathbf{1 . 3 4}$ \\
\hline PD & 15 & 14.26 & 23.30 & $\mathbf{1 8 . 8 8}$ & 1.41 & 1.71 & $\mathbf{1 . 5 5}$ \\
PD & 13 & 18.12 & 19.85 & $\mathbf{1 8 . 9 8}$ & 1.51 & 1.56 & $\mathbf{1 . 5 4}$ \\
PD & 11 & 18.54 & 19.53 & $\mathbf{1 9 . 0 9}$ & 1.52 & 1.55 & $\mathbf{1 . 5 3}$ \\
PD & 8 & 12.74 & 14.37 & $\mathbf{1 3 . 2 2}$ & 1.62 & 1.69 & $\mathbf{1 . 6 6}$ \\
\hline N & 2 & 28.92 & 31.07 & $\mathbf{2 9 . 8 1}$ & 1.36 & 1.41 & $\mathbf{1 . 3 8}$ \\
\hline
\end{tabular}


A comparison of these results with the petrographical characteristics of the diatomites confirms earlier observations of Kotlarczyk et al. (1986) that the lighter-coloured are rock varieties, the higher are their water absorption. In the light-coloured diatomites (varieties BL and PL) and also the variety $\mathrm{BD}$ there is a strong dependence between the water absorption and the silica content $(R=0.81$; $R$ - coefficient of determination), the latter being associated with diatoms. The presence of diatom fossils is the major factor improving the sorption properties of the diatomites. The lower water absorption of the variety PD results from closing many pores or limiting their size because of strong silicification of this diatomite.

\section{Mercury porosimetry tests}

The lowest bulk densities have the diatomites of the variety BL disintegrating into blocks or lumps, while the highest the rocks with the platy and prismatic disintegrations (varieties PL and PD)
(Tab. 6). The values of bulk density established using mercury porosimetry strongly correlate $(R=0.94$; $R$ - coefficient of determination) with the values of apparent density established according to the EN standards (EN-13755:2008, EN-1936:2006) (Fig. 6), and are usually higher by $0.10 \mathrm{~g} / \mathrm{cm}^{3}$. Also total porosity obtained from the porosimetry and the pycnometry correlates well $(R=0.93)$ with water absorption (Fig. 7): the values of total porosity are higher by $3.9-12.4 \%$ than those of water absorption. The difference for the diatomites $\mathrm{BD}$ is two times higher than in the case of the rock of the variety $\mathrm{BL}$, because the pore system of the former rocks is less accessible for water. The resulting conclusion is that the diatomites $\mathrm{BD}$ must possess many narrow, capillary pore throats, through which water at the atmospheric pressure cannot penetrate the pores of the bottle-like shapes because of the surface tension. This conclusion is also supported by a stronger hysteresis effect, marked particularly at high pressures.

Table 6

Parameters derived from mercury porosimetry and helium pycnometry

\begin{tabular}{|c|c|c|c|c|c|c|c|c|c|c|}
\hline $\begin{array}{l}\text { Dia- } \\
\text { tomite } \\
\text { variety }\end{array}$ & $\begin{array}{c}\text { Sample } \\
\text { No. }\end{array}$ & $\begin{array}{c}\text { Bulk } \\
\text { density } \\
{\left[\mathrm{g} / \mathrm{cm}^{3}\right]}\end{array}$ & $\begin{array}{c}\text { Total } \\
\text { porosity }^{(1)} \\
{[\%]}\end{array}$ & $\begin{array}{c}\text { Average } \\
\text { pore- } \\
\text { throat } \\
\text { diameter } \\
\text { [nm] }\end{array}$ & $\begin{array}{l}\text { Thresh- } \\
\text { old pore- } \\
\text { throat } \\
\text { diameter } \\
\text { [nm] }\end{array}$ & $\begin{array}{c}\text { Total } \\
\text { specific } \\
\text { surface } \\
\text { area } \\
{\left[\mathrm{m}^{2} / \mathrm{g}\right]}\end{array}$ & $\begin{array}{l}\text { Hyste- } \\
\text { resis } \\
\text { at } \\
1 \mathrm{MPa} \\
{[\%]}\end{array}$ & $\begin{array}{c}\text { Hyste- } \\
\text { resis } \\
\text { at } \\
10 \mathrm{MPa} \\
{[\%]}\end{array}$ & $\begin{array}{c}\text { Content of } \\
\text { the } \sim 50 \mathrm{~nm} \\
\text { macropores } \\
\text { at } 30 \mathrm{MPa} \\
{[\%]}\end{array}$ & $\begin{array}{l}\text { Line inclina- } \\
\text { tion angle } \\
\text { above } \\
100 \mathrm{MPa}^{(2)} \\
\left.{ }^{\circ}\right]\end{array}$ \\
\hline BL & 17 & 1.28 & 42.98 & 181.5 & 172.5 & 16.1 & 54.5 & 35.2 & 68.1 & 4.9 \\
\hline $\mathrm{BL}$ & 3 & 1.36 & 38.12 & 130.2 & 89.1 & 14.5 & 68.8 & 74.0 & 60.6 & 1.9 \\
\hline BL & $1 \mathrm{C}$ & 1.38 & 40.06 & 181.5 & 136.1 & 12.2 & 78.9 & 42.5 & 70.3 & 1.7 \\
\hline $\mathrm{BL}$ & $1 \mathrm{~A}$ & 1.34 & 41.57 & 181.6 & 110.4 & 13.5 & 72.7 & 52.2 & 65.6 & 1.6 \\
\hline $\mathrm{BD}$ & $14 \mathrm{~B}$ & 1.39 & 37.41 & 130.2 & 92.2 & 15.1 & 79.0 & 77.0 & 53.6 & 2.7 \\
\hline $\mathrm{BD}$ & $12 \mathrm{C}$ & 1.45 & 36.54 & 117.2 & 100.9 & 14.7 & 77.7 & 77.9 & 46.4 & 2.3 \\
\hline $\mathrm{BD}$ & $12 \mathrm{~B}$ & 1.35 & 38.79 & 145.7 & 100.9 & 15.6 & 73.5 & 73.7 & 53.1 & 1.9 \\
\hline $\mathrm{BD}$ & 20 & 1.55 & 33.65 & 130.5 & 94.3 & 13.2 & 76.6 & 78.4 & 48.1 & 2.6 \\
\hline PL & 10 & 1.82 & 26.59 & 117.5 & 1724.7 & 5.0 & 66.7 & 29.4 & 75.7 & 2.1 \\
\hline $\mathrm{PD}$ & 11 & 1.70 & 24.08 & 49.3 & 37.2 & 15.1 & 86.8 & 91.7 & 6.4 & 6.2 \\
\hline $\mathrm{PD}$ & $8^{(3)}$ & 1.78 & 17.13 & 13.0 & n.a. & 3.0 & n.a. & n.a. & 15.7 & 46.0 \\
\hline $\mathrm{N}$ & 2 & 1.36 & 42.19 & 181.5 & 163.8 & 14.8 & 76.4 & 44.4 & 65.9 & 2.5 \\
\hline
\end{tabular}

Notes: ${ }^{(1)}$ - total porosity calculated using the results of mercury porosimetry and helium pycnometry.

(2) - the line approximating the final section of the intrusion curve above $100 \mathrm{MPa}$.

(3) - sample damaged at a pressure of around $100 \mathrm{MPa}$.

n.a. - not analysed due to the sample damage. 


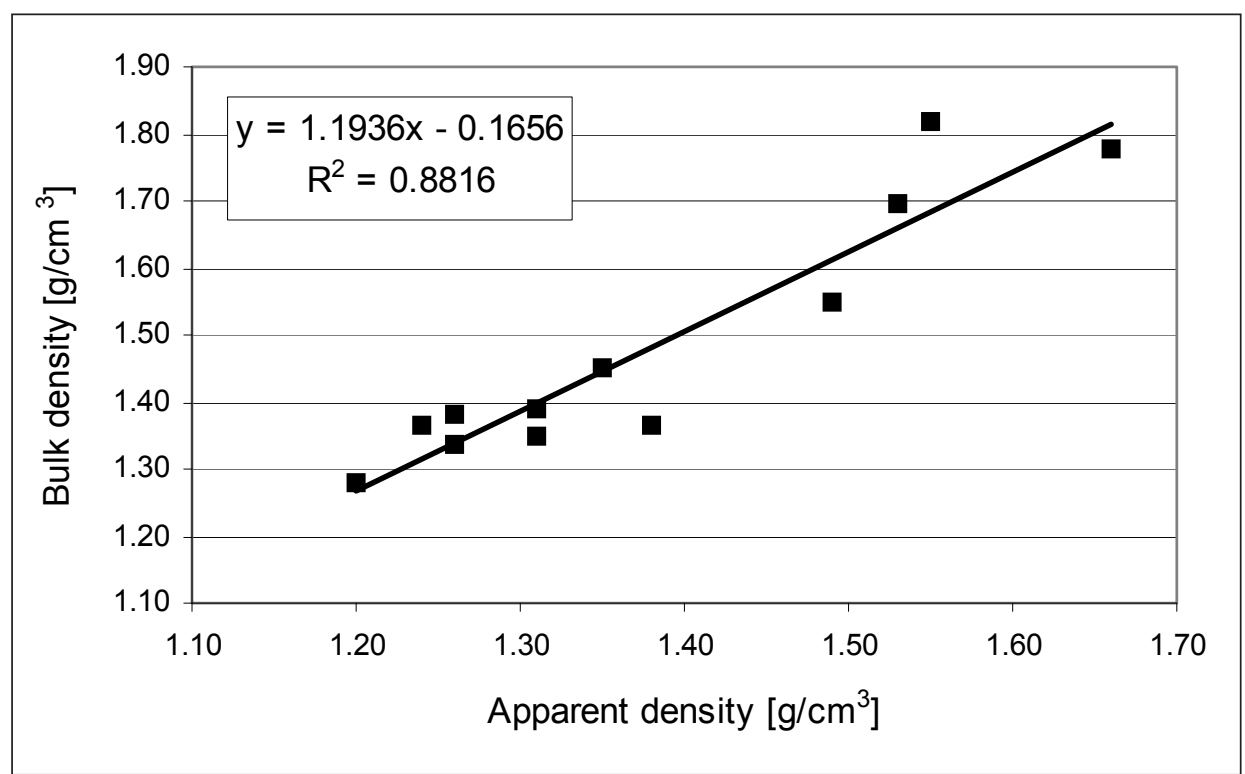

Fig. 6. Relation between apparent density and bulk density of diatomites measured by hydrostatic weighing and porosimetry methods, respectively

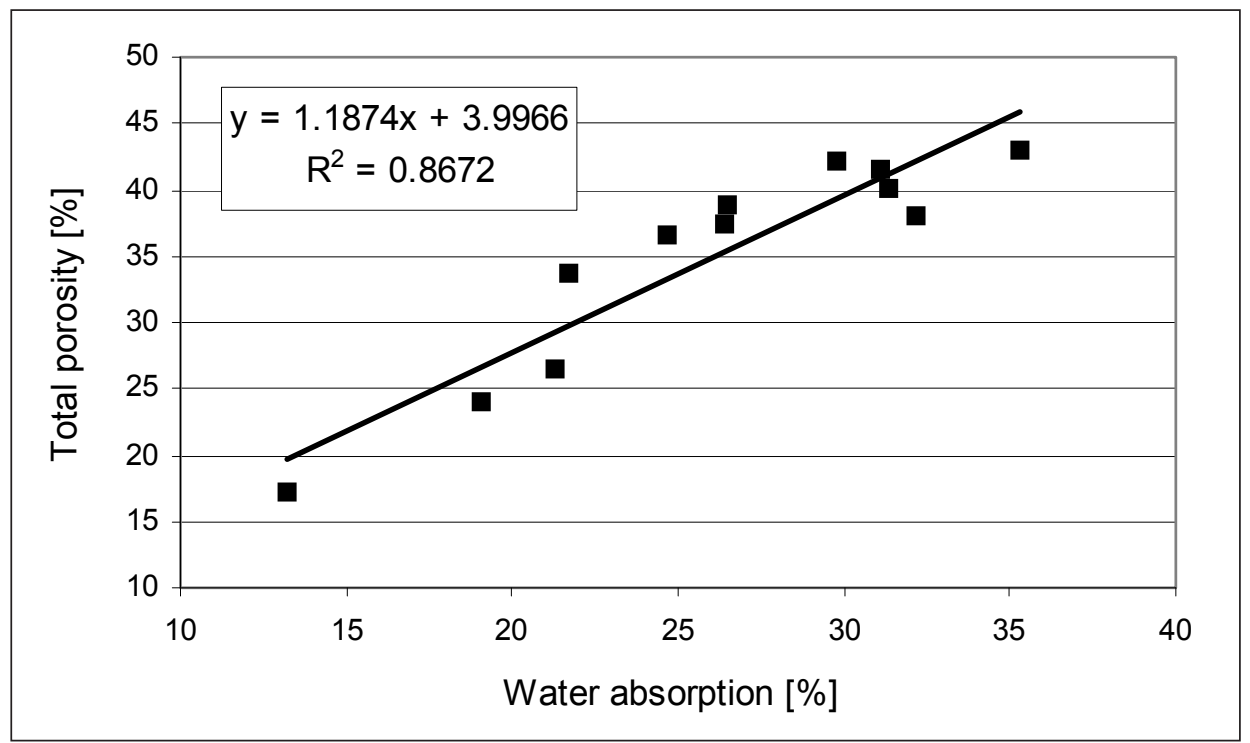

Fig. 7. Relation between water absorption and total porosity of diatomites measured by hydrostatic weighing and porosimetry methods, respectively

The dark- and light coloured (BD and $\mathrm{BL})$ diatomites also differ in their pore size distributions. Although the shapes of their intrusion curves are similar, the curves of the variety $\mathrm{BD}$ have their inflection points shifted towards higher pressures (it corresponds to lower pore-throat sizes). Thus, a significant role of the pores begins only from the diameters around $100 \mathrm{~nm}$, whereas in the variety $\mathrm{BL}$ the threshold of pore-throat diameter reaches even $170 \mathrm{~nm}$ (sample 17, Tab. 6). Therefore, the light-coloured diatomites with blocky disintegration must have a higher (by $60-70 \%$ ) content of larger pores $(>50 \mathrm{~nm})$, termed as macropores (Rouquerol et al. 1994), which are easily accessible for the infilling medium and facilitate its relatively free evacuation at decreasing pressure. It is corroborated by the hysteresis values at $10 \mathrm{MPa}$ ranging for the diatomites $\mathrm{BL}$ from $35 \%$ to $74 \%$ while for the blocky diatomites BD from $74 \%$ to $78.5 \%$. The presence of the pore-throats with smaller diameters in the variety $\mathrm{BD}$ than those in the variety $\mathrm{BL}$ results also from a higher inclination 
angle of the line approximating the position of the final section of the intrusion curve, i.e., at the pressures above $100 \mathrm{MPa}$ (Fig. 8A). It proves the presence of pores with the diameters less than $10 \mathrm{~nm}$, which could be filled with mercury if higher pressures (above $150 \mathrm{MPa}$ ) were applied.

An example of such a situation is sample 17 of the blocky, light-coloured diatomites BL. At a high threshold pore-throat diameter of around $170 \mathrm{~nm}$, this rock also contains very small pores, below $10 \mathrm{~nm}$, which is proved by a final section of the approximating line, for which the inclination is around $5^{\circ}$. In addition, the distribution of pore sizes is bimodal with the mode values at $270 \mathrm{~nm}$ and the other close to $10 \mathrm{~nm}$. The sorption properties of these diatomites are exceptionally advantageous, resulting from their highest total porosity and a high content of macropores, simultaneously at a relatively high content of very small pores; the real pore space of these diatomites approximates best the model of cyllindrical capillaries (weak hysteresis effect) (Fig. 8A).

A bimodal pore size distribution characterizes also sample No. 10 (variety PL). The pore system of this diatomite is composed of particularly numerous pores with the diameters around $1160 \mathrm{~nm}$ and $100 \mathrm{~nm}$ (Fig. 8B). The larger pores represent probably the intergranular ones and the hollows within the frustules of diatoms. The content of macropores is close to $76 \%$ and is the highest of all the diatomite varieties; the average throatpore diameter is $117.5 \mathrm{~nm}$. Beneficial filtration properties are attributed to a very high threshold diameter of about $1725 \mathrm{~nm}$ and the lowest value of the hysteresis effect at the pressure $10 \mathrm{MPa}$. As the disadvantageous property is low porosity, and it is one of the lowest measured, equal only to $26.59 \%$.
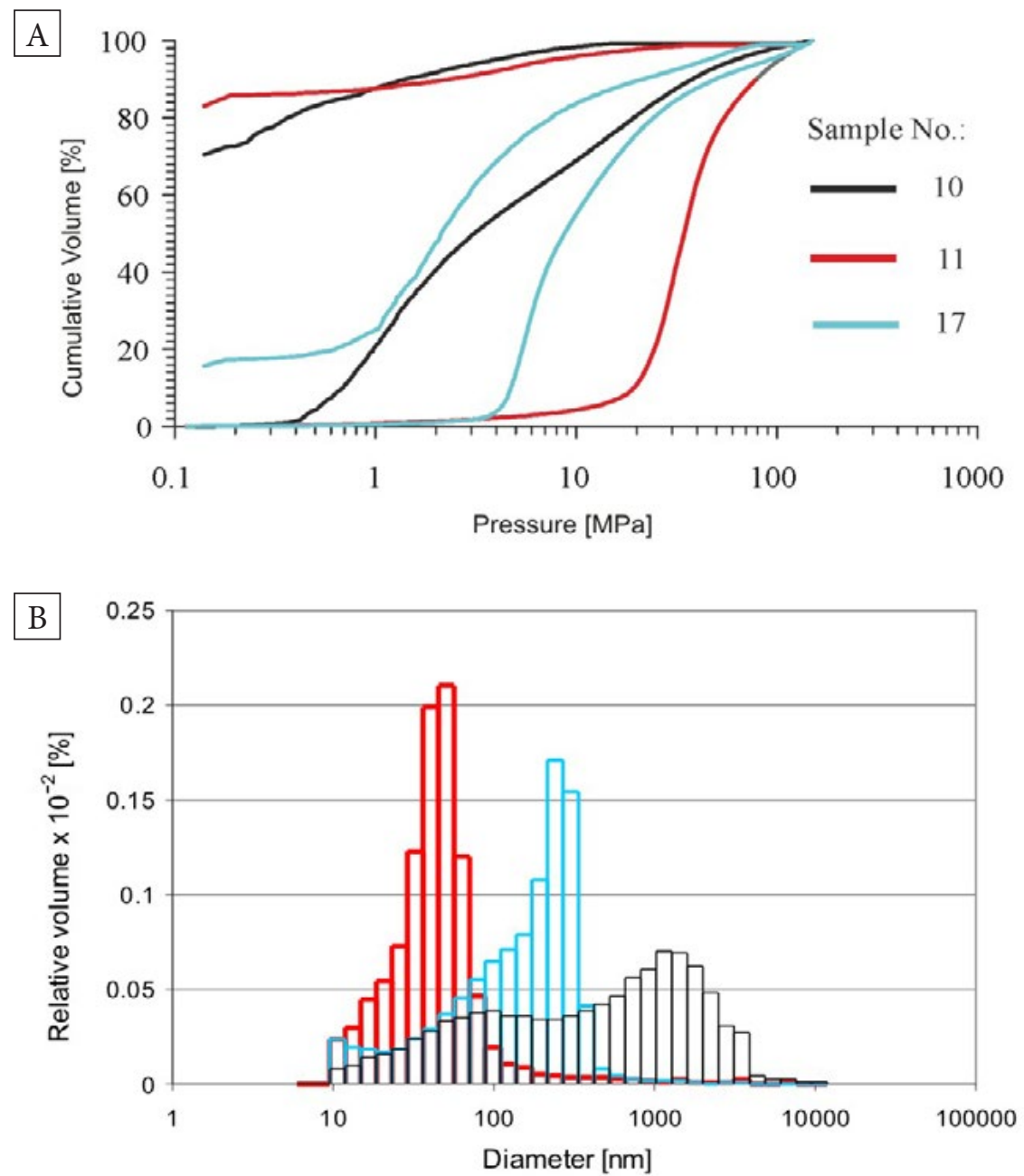

Fig. 8. Cumulative (A) and relative (B) pore volume distributions of diatomaceous rocks from the Jawornik deposit 
The minimum porosities possess the diatomites of the variety $\mathrm{PD}$, particularly the highly silicified sample from the layer No. 8. (17.13\%; Tab. 6), in which the content of macropores is only $15.7 \%$. The intrusion curve of this sample indicated an increasing filling rate of the pores with mercury, which at the pressure close to $100 \mathrm{MPa}$ resulted in damaging the internal structure of the sample and in formation of test-induced fractures. Therefore, the withdrawal curve was already of no meaning. From the course of the test one conclusion about the rock may be drawn: probably even its smallest pores $(<16 \mathrm{~nm})$ are filled with silica.

The nodular diatomite variety $(\mathrm{N})$, represented by sample 2 , has similar values of the total porosity, average pore diameter and other pore-related parameters as the light-coloured blocky diatomites $\mathrm{BL}$.

The total specific surface area of most of the samples ranges between $12 \mathrm{~m}^{2} / \mathrm{g}$ and $16 \mathrm{~m}^{2} / \mathrm{g}$ and does not show any relation to the diatomite variety. The exception make the rocks with platy and prismatic disintegrations. The light-coloured diatomite PL (sample 10) has a specific surface area of only a $5.0 \mathrm{~m}^{2} / \mathrm{g}$, which is caused by its high content of macropores. Still lower value of this parameter is a feature of sample 8 , which represents the silicified diatomite and has low total porosity and does not possess the pores of smallest sizes.

\section{Microindentation hardness test}

The Vickers hardness of the Jawornik diatomites ranges between $9.2 \mathrm{HV}_{0.3}$ and $23.2 \mathrm{HV}_{0.3}$ except for the silicified diatomite of the variety PD (sample 8), whose hardness is several times higher, equal to $80.8 \mathrm{HV}_{0.3}$ (Tab. 7). Such a difference results from a high content of the siliceous groundmass that strongly binds granular components, i.e., diatoms and mineral grains. In hand specimens it is marked by a characteristic disintegration of the rock into sharp-edged fragments.

There is a dependence between the total porosity of diatomites and their microhardness. The high porous diatomaceous rocks representing the varieties BL and $\mathrm{N}$ characterize the lowest microhardness. Whereas the poorly porous varieties of $\mathrm{BD}$ and $\mathrm{PD}$ possess higher hardness, however an exception is the variety PL. The lowest hardness 9.2 $\mathrm{HV}_{0.3}$ of the PL diatomite (sample 10) is a result of its highest content of macropores and highest average diameter of pores at a relatively low total porosity. These parameters are accompanied by large contents of granular components. Such features combined together cause a fast damage of the sample framework when an indenter is driven into the sample during the microhardness test. In addition, this diatomite must contain a significant amount of clay minerals as inferred from its highest $\mathrm{Al}_{2} \mathrm{O}_{3}$ content; clay minerals are an obvious reason of lowering the rock hardness. Softening of some samples from the layers 10 and 20 was a result of their saturating with water.

Table 7

Results of the Vickers test

\begin{tabular}{|c|c|c|c|c|}
\hline $\begin{array}{c}\text { Diatomite } \\
\text { variety }\end{array}$ & $\begin{array}{c}\text { Sample } \\
\text { No. }\end{array}$ & $\begin{array}{c}\mathbf{H V}_{\mathbf{0 . 3}} \\
{\left[\mathbf{g f} / \boldsymbol{\mu m}^{2}\right]}\end{array}$ & Range & $\begin{array}{c}\text { Standard } \\
\text { deviation }\end{array}$ \\
\hline $\mathrm{BL}$ & 17 & 10.7 & $8.5-13.9$ & 1.62 \\
\hline $\mathrm{BD}$ & 20 & 15.8 & $11.7-20.7$ & 2.69 \\
$\mathrm{BD}$ & $14 \mathrm{~A}$ & 23.2 & $15.7-26.6$ & 3.32 \\
$\mathrm{BD}$ & $12 \mathrm{~B}$ & 13.6 & $12.1-15.7$ & 0.80 \\
\hline $\mathrm{PL}$ & 10 & 9.2 & $7.6-11.5$ & 1.10 \\
\hline $\mathrm{PD}$ & 8 & 80.8 & $44.4-130.0$ & 9.65 \\
\hline $\mathrm{N}$ & 2 & 10.5 & $6.2-14.1$ & 2.05 \\
\hline
\end{tabular}

There is no direct dependence between the silica $\left(\mathrm{SiO}_{2}\right)$ content and the hardness of the diatomites, since the value of the latter parameter is modified by additional factors, i.e., the form of silica development, the rock porosity and the content of clay minerals.

\section{CONCLUSIONS}

The petrographic analyses, in which the authors combines the results of microscope investigations and chemical analyses indicate that despite diversified ratios of diatoms to clay minerals to granular components, the rocks from Jawornik mostly belong in the classification of Owen \& Utha-aroon (1999) to the group of the clayey diatomites, while two of the varieties distinguished, i.e. PL and N, are located between the clayey diatomites and diatomaceous clays.

The best sorption properties possess massive, light-coloured diatomites $\mathrm{BL}$ that disintegrate into blocks, which are characterized by the lowest 
values of apparent density $\left(1.20-1.26 \mathrm{~g} / \mathrm{cm}^{3}\right)$ and the highest total porosity $(38-43 \%)$. The pore structure of these rocks being dominated by macropores $(60-71 \%)$ is the closest to that arrived at in the model of cylindrical capillaries with a high degree of complication, the conclusion also corroborated by high values of their fractal sizes (Stańczak et al. 2015).

Slightly worse are the sorption properties of dark-coloured diatomites also disintegrating into blocks (BD): apparent density $1.31-1.49 \mathrm{~g} / \mathrm{cm}^{3}$, total porosity $33-39 \%$, distinctly lower content of macropores $46-54 \%$. The diatomites of both these varieties are rich in silica, mostly developed as opal-A and present in the diatom frustules. Less silica occurs in the groundmass also as opal-A, as a chemical component of clay minerals, representing a product of hydrolysis of pyroclastic deposits, and finally as detrital quartz. In the diatomites $\mathrm{BL}$ and $\mathrm{BD}$, the compaction of their sediments is rather weakly expressed. There are only occasional signs of diagenetic dissolving of diatoms, reprecipitation of the silica formed, and then recrystallization of this silica resulting with the formation of opal CT in the diatomite pores and intergranular spaces. Despite the prevalent content of $\mathrm{SiO}_{2}$ in relation to other chemical components, these diatomites are rather soft. Their microhardness is only $10.7 \mathrm{HV}_{0.3}$, and at the presence of better ordered silica in the groundmass the rock microhardness increases to even 23.2 $\mathrm{HV}_{0.3}$. The diatomites $\mathrm{BL}$ and $\mathrm{BD}$ form layers of a considerable thickness ranging from 2 to almost $10 \mathrm{~m}$ and in the trench sampled make up together $71.5 \%$ of its thickness and are a characteristic and easily distinguishable rock within the Jawornik deposit.

The light-coloured diatomite variety with a platy or prismatic disintegration (PL) forms three layers with diversified thickness from $0.3 \mathrm{~m}$ to $2.5 \mathrm{~m}$, whose contribution to the total thickness of the profile is only $8.0 \%$. These rocks have the apparent density close to those of the variety $\mathrm{BD}$ but distinctly lower total porosity, around $26 \%$. Their pore system is composed of the pores of diversified, mostly large sizes, which is proved by the highest content of macropores $(75.7 \%)$ of all the diatomites. Due to the high amount of clay minerals, the presence of amorphous silica in the groundmass and high porosity, the rocks of the variety PL have the lowest of all the diatomites hardness equal to $9.2 \mathrm{HV}_{0.3}$.
The dark-coloured diatomite variety with a platy or prismatic disintegration (PD) makes up only $3.0 \%$ of the profile and occurs as $0.2-0.6 \mathrm{~m}$ thick layers, one of them being strongly silicified. In relation to the rocks characterized above, these diatomites possess the highest apparent density $\left(1.53-1.66 \mathrm{~g} / \mathrm{cm}^{3}\right)$ and the lowest total porosity (17-24\%). Their pore space is composed of the pores with the diameters in a narrow range and with the lowest content of macropores (6.4\%) of all the diatomites. The finest pores with a size of fifteen or so nanometers in the rocks with stronger silicification (their $\mathrm{SiO}_{2}$ content is around $85 \mathrm{wt} . \%$ and an amount of detrital minerals small) are filled with silica. Such properties result from diagenesis stronger in these diatomites than in the remaining varieties. The diatom fossils are strongly fragmented and show signs of dissolution. As the diatom content of these rocks is the lowest and equals only 44.7 vol.\%, it may be a result of dissolution of the finest frustules. The released silica reprecipitated probably as opal-A' and sealed the small pores within the frustule structure, and also filled, fully or in part, the pores among detrital grains. The intergranular silica also recrystallized later but into opal-CT identified with the X-ray method. The presence of the silica with a higher ordering is also indicated by the highest microhardness of this diatomite equal to $80.8 \mathrm{HV}_{0.3}$, although such hardness is also due to the low porosity of the rock and a small amount of clay minerals. An additional source of silica, derived from a hydrolised pyroclastic material, may be suggested for this diatomite. Its layer is immediately underlain and overlain by shales containing high amounts of smectites. Such strata, but containing also clinoptilolite, were identified within the Skole Unit (Wieser 1969, Rajchel 1990) and interpreted (Wieser 1969) as the deposits with admixtures of volcanic glass. A volcanic activity in this region was also proved by horizons of dacitic tuffites with the thickness reaching $2.5 \mathrm{~m}$, described in the Upper Krosno Beds by Szymakowska (1959).

Diatomites with the nodular disintegration (variety $\mathrm{N}$ ) occur in one layer only, but well visible in the quarry due to its strikingly different yellowish orange colour. The colour obviously results from iron compounds, calculated here as 17.24\% $\mathrm{Fe}_{2} \mathrm{O}_{3}$, which is extremly higher than in other diatomite varieties. Iron must be bound in 
amorphous oxides/hydroxides that fill micropores among the microfossils, detrital components and the groundmass of the rock. The presence of hematite but in the Krosno sandstones and its origin explained as a transformation of iron hydroxides at the contact with meteoric waters (Such 2007).

The presence within the Jawornik deposits the clayey diatomites that represent most of the rocks studied results in a considerable variability of the physical and mechanical properties of these rocks and of their chemical composition. Extraction of rocks without a proper selection of mining sites results in obtaining the raw material with averaged properties that depend on the contribution of the diatomite variety prevailing in a given part of deposit. With respect to the dominant amount of the rock varieties $\mathrm{BL}$ and $\mathrm{BD}$, the excavated diatomite material has the advantageous bulk density equal to $1.3 \mathrm{~g} / \mathrm{cm}^{3}$ (weighted average for the pit profile) and total porosity equal to $36.9 \%$. Its hardness is not high and equals $13.3 \mathrm{HV}_{0.3}$, whereas the chemical composition is the dominated by $\mathrm{SiO}_{2}$ (77.4 wt.\%) and accompanied by 8.7 wt. $\% \mathrm{Al}_{2} \mathrm{O}_{3}$ and 2.5 wt. $\% \mathrm{Fe}_{2} \mathrm{O}_{3}$. The diatomite raw material with high sorption properties may only be obtained applying a selective extraction of the massive diatomite layers distinguishable due to their blocky disintegration; particularly desirable would be their light creamy variety BL.

This work was financially supported by the AGH UST statutory grant No. 11.11.140.320.

\section{REFERENCES}

Avramenko A.S., Cherepanova M.V., Pushkar V.S. \& Yarusova S.B., 2015. Diatom characteristics of the Far East siliceous organogenic deposits. Russian Geology and Geophysics, 56, 947-958.

Borkowska M. \& Smulikowski K., 1973. Minerały skałotwórcze. Wydawnictwa Geologiczne, Warszawa.

Bolewski A. \& Manecki A., 1993. Mineralogia szczegółowa. Wydawnictwo PAE, Warszawa.

Bromowicz J. \& Górniak K., 1988. Litologia i sedymentacja margli łąckich wschodniej części płaszczowiny magurskiej (Karpaty fliszowe). Annales Societatis Geologorum Poloniae, 58, 385-421.

Christmann P., 2010. Critical minerals to the EU economy: issues and potential. [in:] Martens P.N. (ed.), Aachen International Mining Symposia, VGE Verlag, Essen, 19-34.

Derkowski A., Środoń J. \& McCarty D.K., 2015. Cation exchange capacity and water content of opal in sedimentary basins: Example from the Monterey Formation, California. American Mineralogist, 100, 1244-1256.
Ediz N., Bentli İ. \& Tatar İ., 2010. Improvement in filtration characteristics of diatomite by calcination. International Journal of Mineral Processing, 94, 129-134.

Elzea J.M., Odom I.E. \& Miles W.J., 1994. Distinguishing well ordered opal-CT and opal-C from high temperature cristobalite by x-ray diffraction. Analytica Chimica Acta, 286, 107-116.

Emmerich K., Steudel A., Schuhmann R., Weidler P.G., Ruf F. \& Sohling U., 2010. Mineralogical and physicochemical characterization of a natural bleaching earth containing sepiolite suitable for fast filtration and bioseparation. Clay Minerals, 45, 477-488.

EN-13755:2008. Natural stone test methods - Determination of water absorption at atmospheric pressure. CEN European Committee for Standarization.

EN-1936:2006. Natural stone test methods - Determination of real density and apparent density, and of total and open porosity. CEN European Committee for Standarization.

Flörke O.W., Gratesch H., Martin B., Röller K. \& Wirth R., 1991. Nomenclature of microcrystalline and non-crystalline silica minerals, based on structure and microstructure. Neues Jahrbuch Für Mineralogie - Abhandlungen, 163, 1, 19-42.

van Garderen N., Clements F.J., Mezzomo M., Perez Bergmann C. \& Graule T., 2011. Investigation of clay content and sintering temperature on attrition resistance of highly porous diatomite based material. Applied Clay Science, 52, 115-121.

Glinicki M.A., Kasperkiewicz J., Sobczak M. \& Zieliński M., 2003. Badanie mikrotwardości betonu za pomocą wgłębnika Vickersa. [in:] XLIX Konferencja Naukowa Komitetu Inżynierii Ladowej $i$ Wodnej PAN i Komitetu Nauki PZITB „Krynica 2003”: problemy naukowo-badawcze budownictwa, Warszawa - Krynica, 14-19 września 2003 r. T. 3, Konstrukcje betonowe, materialy budowlane, Oficyna Wydawnicza Politechniki Warszawskiej, Warszawa, 139-146.

Granops M., 1989. Badania nad przydatnością diatomitów karpackich w uzdatnianiu wody i oczyszczaniu ścieków. Zeszyty Naukowe Politechniki Rzeszowskiej. Budownictwo i Inżynieria Środowiska, 56, 9, 3-74.

Graetsch H., 1994. Structural characteristics of opaline and micro-crystalline silica minerals. [in:] Heaney P.J., Prewitt C.T. \& Gibbs G.V. (eds), Silica. Physical Behaviour, Geochemistry and Materials Applications, Reviews in Mineralogy, 29, 209-232.

Hein J.R. \& Scholl D.W., 1978. Diagenesis and distribution of late Cenozoic volcanic sediment in the southern Bering Sea. Geological Society of America Bulletin, 89, 197-210.

Hurd D.C., 1973. Interactions of biogenic opal, sediment and seawater in the Central Equatorial Pacific. Geochimica et Cosmochimica Acta, 37, 2257-2282.

Ibrahim S.S. \& Selim A.Q., 2010. Producing a micro-porous diatomite by a simple classification-calcinations process. The Journal of Ore Dressing, 12, 23, 24-32.

Iler R., 1979. The Chemistry of Silica: Solubility, Polymerization, Colloid and Surface Properties and Biochemistry of Silica. Wiley Interscience, New York.

Janotka I., Krajči L., Uhlík P. \& Bačuvčík M., 2014. Natu$\mathrm{ral}$ and calcined clayey diatomite as cement replacement materials: microstructure and pore structure study. International Journal of Research in Engineering and Technology, 3, 13, 20-26. 
Jin J., Zheng C. \& Yang H., 2014. Natural diatomite modified as novel hydrogen storage material. Functional Materials Letters, 7, 3, 1450027-1-4.

Jones J.B. \& Segnit E.R., 1971. The nature of opal. I. Nomenclature and constituent phases. Journal of the Geological Society of Australia, 18, 57-68.

Jones J.B. \& Segnit E.R., 1972. Genesis of cristobalite and tridymite at low temperatures. Australian Journal of Earth Sciences, 18, 4, 419-422.

Jucha S. \& Kotlarczyk J., 1961. Seria menilitowo-krośnieńska w Karpatach fliszowych. Prace Geologiczne - Polska Akademia Nauk. Oddział w Krakowie. Komisja Nauk Geologicznych, 4, Wydawnictwa Geologiczne, Warszawa.

Kaleta J., Papciak D. \& Puszkarewicz A., 2007. Klinoptylolity i diatomity $\mathrm{w}$ aspekcie przydatności w uzdatnianiu wody i oczyszczaniu ścieków. Gospodarka Surowcami Mineralnymi, 23, 3, 21-34.

Kastner M., Keene J.B. \& Gieskes J.M., 1977. Diagenesis of Siliceous Oozes. 1. Chemical Controls on Rate of Opal-A to Opal-CT Transformation - Experimental Study. Geochimica et Cosmochimica Acta, 41, 1041-1059.

Koszarski L. \& Żytko K., 1961. Jasło Shales within the Menilite-Krosno Series in the Middle Carpathians. Biuletyn Instytutu Geologicznego, 166, 87-232.

Kotlarczyk J., 1955. O występowaniu diatomitu we fliszu Karpat polskich. Przeglad Geologiczny, 5, 244.

Kotlarczyk J., 1966. Poziom diatomitowy $z$ warstw krośnieńskich na tle budowy geologicznej jednostki skolskiej w Karpatach polskich. Studia Geologica Polonica, 19, Wydawnictwa Geologiczne, Warszawa.

Kotlarczyk J., 1982. The role of diatoms in sedimentation and biostratigraphy of the Polish Flysch Carpathians. Acta Geologica Academiae Scientiarum Hungaricae, 25, $1-2,9-21$.

Kotlarczyk J., 1988a. Jawornik Ruski - kopalnia diatomitu. Poziom diatomitów z Leszczawki, najmłodsza olistostroma we fliszu. [in:] Kotlarczyk J., Pękala K. \& Gucik S. (red.), Karpaty Przemyskie. Przewodnik 59 Zjazdu Polskiego Towarzystwa Geologicznego, Przemyśl, 16-18 września 1988, Wydawnictwa AGH, Kraków, 115-118.

Kotlarczyk J., 1988b. Poziom diatomitów z Leszczawki. Punkt B-3. Jawornik Ruski. 1. Geologia i własności surowca. [in:] Kotlarczyk J., Pękala K. \& Gucik S. (red.), Karpaty Przemyskie. Przewodnik 59 Zjazdu Polskiego Towarzystwa Geologicznego, Przemyśl, 16-18 września 1988, Wydawnictwa AGH, Kraków, 149-154.

Kotlarczyk J. \& Kaczmarska I., 1987. Two diatoms horizons in the Oligocene and (?) Lower Miocene of the Polish Outer Carpathians. Annales Societatis Geologorum Poloniae, 57, 143-188.

Kotlarczyk J. \& Leśniak T., 1990. Dolna część formacji menilitowej $z$ poziomem diatomitów $z$ Futomy $w$ jednostce skolskiej polskich Karpat. Wydawnictwa AGH, Kraków.

Kotlarczyk J., Brożek M. \& Michalski M., 1986. Diatomity polskich Karpat - występowanie, jakość, przeróbka i zastosowania. Gospodarka Surowcami Mineralnymi, 2, 3-4, 497-523.

Li X., Li X. \& Wang G., 2007. Surface modification of diatomite using polyaniline. Materials Chemistry and Physics, 102, 140-143.

Losic D., Pillar R.J., Dilger T., Mitchell J.G. \& Voelcker N.H., 2007. Atomic force microscopy (AFM) characterisation of the porous silica nanostructure of two centric diatoms. Journal of Porous Materials 14, 61-69.

Malata T., 1996. Analiza formalnych wydzieleń litostratygraficznych oraz propozycja podziału jednostki skolskiej polskich Karpat fliszowych. Przeglad Geologiczny, 44, 5, 509-513.

Malata T. \& Poprawa P., 2006. Ewolucja subbasenu skolskiego. [in:] Oszczypko N., Uchman A. \& Malata E. (red.), Rozwój paleotektoniczny basenów Karpat zewnętrznych i pienińskiego pasa skałkowego, Instytut Nauk Geologicznych Uniwersytetu Jagiellońskiego, Kraków, 103-110.

Marcinowski R., Mardal R. \& Piotrowska K., 2011. Słownik jednostek litostratygraficznych Polski. Wersja podstawowa (grudzień 2004-2011). PIG, [on-line:] http://slp.pgi. gov.pl/index.php.

Martinovic S., Vlahovic M., Boljanac T. \& Pavlovic L., 2006. Preparation of filter aids based on diatomites. International Journal of Mineral Processing, 80, 255-268.

Maynard J.B., 1975. Kinetics of silica adsorption by kaolinite with application to seawater chemistry. American Journal of Science, 275, 1028-1048.

Osmanlioglu A.E., 2007. Natural diatomite process for removal of radioactivity from liquid waste. Applied Radiation and Isotopes 65, 17-20.

Oszczypko N., 2008. Outher Carpathians in Poland. [in:] McCann T. (ed), The Geology of Central Europe. Volume 2: Mesozoic and Cenozoic, Geological Society, London, 1078-1081.

Owen R.B. \& Utha-aroon C., 1999. Diatomaceous sedimentation in the Tertiary Lampang Basin, Northern Thailand. Journal of Paleolimnology, 22, 81-95.

Pawloski G.A., 1985. Quantitative determination of mineral content of geological samples by X-Ray diffraction. American Mineralogist, 70, 663-667.

Pedersen G.K. \& Surlyk F., 1983. The Fur Formation, a late Palaeocene ash-bearing diatomite from northern Denmark. Bulletin of the Geological Society of Denmark, 32, 43-65.

Puszkarewicz A., 2004. Diatomity w ochronie środowiska. Zeszyty Naukowe Politechniki Rzeszowskiej. Budownictwo i Inżynieria Środowiska, 218, 38, 109-118.

Radwanek-Bąk B., 2011. Zasoby kopalin Polski w aspekcie oceny surowców krytycznych Unii Europejskiej. Gospodarka Surowcami Mineralnymi, 27, 1, 5-19.

Rajchel J., 1990. Litostratygrafia osadów górnego paleocenu i eocenu jednostki skolskiej. Zeszyty Naukowe - Akademia Górniczo-Hutnicza, 1369. Geologia, 48, Akademia Górniczo-Hutnicza, Kraków [with English summary].

Rouquerol J., Avnir D., Fairbridge C.W., Everett D.H., Haynes J.H., Pernicone N., Ramsay J.D.F., Sing K.S.W. \& Unger K.K., 1994. Recommendations for the characterization of porous solids (Technical Reports). Pure \& Applied Chemistry, 66, 8, 1739-1758.

Russocki Z., 1981. Zmienność diatomitów w złożu Leszczawka. [in:] Szymańska A. (red.), Nowe kierunki zastosowań diatomitów polskich $w$ gospodarce narodowej: konferencja naukowo-techniczna, Przemyśl, 23-24 maja 1980, Wydawnictwa Geologiczne, Warszawa, 30-40.

Siever R. \& Woodford N., 1973. Sorption of silica by clay minerals. Geochimica et Cosmochimica Acta, 37, 1851-1880.

Sigg L. \& Stumm W., 1981. The interaction of anions and weak acids with the hydrous goethite $(\alpha-\mathrm{FeOOH})$ surface. Colloids \& Surfaces, 2, 101-107. 
Smoleńska A. \& Rembiś M., 2002. Diatomit jako lekkie kruszywo mineralne w tynkach renowacyjnych. [in:] Kruszywa mineralne: surowce, rynek, technologie, jakość: Polanica Zdrój 17-19 kwietnia 2002, Prace Naukowe Instytutu Górnictwa Politechniki Wrocławskiej, 97. Konferencje, 33, Oficyna Wydawnicza PW, Wrocław, 197-203.

Sohling U., Ruf F., Schurz K., Emmerich K., Steudel A., Schuhmann R., Weidler P., Ralla K., Riechers D., Kasper C. \& Scheper T., 2009. Natural mixture of silica and smectite as a new clayey material for industrial applications. Clay Minerals, 44, 525-537.

Stańczak G., Rembiś M., Figarska-Warchoł B. \& Toboła T., 2015. Fractal characteristics of the pore network in diatomites using mercury porosimetry and image analysis [in:] Polychroniadis E.K., Oral A.Y. \& Ozer M. (eds), 2nd International Multidisciplinary Microscopy and Microanalysis Congress, Proceedings of InterM, October 16-19, 2014, Springer Proceedings in Physics, 164, 79-89.

Such P., 2007. Prognozowanie cech petrofizycznych formacji ropogazonośnych i kwalifikacja naftowa potencjalnych skał zbiornikowych. [in:] Górecki W. \& Kuśmierek J. et al., Dokumentacja merytoryczna projektu PBS/ PUPW/6/2005, pn. „Badania transgraniczne wgłębnych struktur geologicznych brzeżnej strefy Karpat w aspekcie odkryć $i$ udostępnienia nowych złóż ropy naftowej i gazu ziemnego". Blok V, Archiwum KSE AGH, Kraków.

Sungworawongpana S. \& Pengprecha S., 2011. Calcination Effect of Diatomite to Chromate Adsorption. Procedia Engineering, 8, 53-57.

Szydło A., Garecka M., Jankowski L. \& Malata T., 2014. Paleogene microfossils from the submarine debris flows in the Skole Basin (Polish and Ukraine Outer Carpathians). Geology, Geophysics \& Environment, 40, 1, 49-65.

Szymakowska F., 1959. Rozwój warstw krośnieńskich w niektórych obszarach Karpat Środkowych. Geological Quarterly, 3, 3, 620-637.

Śliwowa M. \& Russocki Z., 1980. Dokumentacja geologiczna złoża diatomitów Leszczawka, pole Jaworowice-Borow- nica w kat. C1+C2. Gmina Bircza. Woj. przemyskie. OBR-GSChem, Kraków.

Toboła T., Rembiś M., Figarska-Warchoł B. \& Stańczak G., 2015. Fibrous growth of chloride minerals on diatomite saturated with a brine. [in:] Polychroniadis E.K., Oral A.Y. \& Ozer M. (eds), 2nd International Multidisciplinary Microscopy and Microanalysis Congress, Proceedings of InterM, October 16-19, 2014, Springer Proceedings in Physics, 164, 73-78.

Vavra C.L., Kaldi J.G. \& Sneider R.M., 1992. Geological applications of capillary pressure: a review. American Association of Petroleum Geologists Bulletin, 76, 6, 840-850.

Washburn E.W., 1921. The dynamics of capillary flow. Physical Review, 17, 3, 273-283.

Wey R. \& Siffert B., 1961. Réactions de la silice monomoléculaire en solutions avec les ions $\mathrm{Al}^{3+}$ et $\mathrm{Mg}^{2+}$. Colloques Internationaux, 105, Centre National des Recherches Scientifiques, 11-23.

Wieser T., 1969. Clinoptilolite from Lower Eocene Variegated Shales of the external Flysch Carpathians. Bulletin of the Polish Academy of Sciences, 17, 123-129.

Williams L.A. \& Crerar D.A., 1985. Silica diagenesis. II. General mechanisms. Journal of Sedimentary Petrology, 55, 312-321.

Williams L.A., Parks G.A. \& Crerar D.A., 1985. Silica Diagenesis, I. Solubility Controls. Journal of Sedimentary Petrology, 55, 301-311.

Winkler E.M., 1997. Stone in Architecture: properties, durability. 3 ed. Springer, Berlin.

Xiong P. \& Peng J., 2008. Development and characterization of ferrihydrite-modified diatomite as a phosphorus adsorbent. Water Research, 42, 4869-4877.

Yllmaz B. \& Ediz N., 2008. The use of raw and calcined diatomite in cement production. Cement \& Concrete Composites, 30, 202-211.

Żgiet J., 1963. Spostrzeżenia nad sedymentacją wkładek diatomitów i tufów w Karpatach. Kwartalnik Geologiczny, 7, 714-715. 